\title{
Glacial history of Mt Chelmos, Peloponnesus, Greece
}

DOI:

10.1144/SP433.11

\section{Document Version}

Accepted author manuscript

Link to publication record in Manchester Research Explorer

\section{Citation for published version (APA):}

Pope, R. J., Hughes, P. D., \& Skourtsos, E. (2015). Glacial history of Mt Chelmos, Peloponnesus, Greece.

Geological Society, London, Special Publications, 433. https://doi.org/10.1144/SP433.11

\section{Published in:}

Geological Society, London, Special Publications

\section{Citing this paper}

Please note that where the full-text provided on Manchester Research Explorer is the Author Accepted Manuscript or Proof version this may differ from the final Published version. If citing, it is advised that you check and use the publisher's definitive version.

\section{General rights}

Copyright and moral rights for the publications made accessible in the Research Explorer are retained by the authors and/or other copyright owners and it is a condition of accessing publications that users recognise and abide by the legal requirements associated with these rights.

\section{Takedown policy}

If you believe that this document breaches copyright please refer to the University of Manchester's Takedown Procedures [http://man.ac.uk/04Y6Bo] or contact uml.scholarlycommunications@manchester.ac.uk providing relevant details, so we can investigate your claim.

\section{OPEN ACCESS}


The glacial history of Mount Chelmos, Peloponnesus, Greece

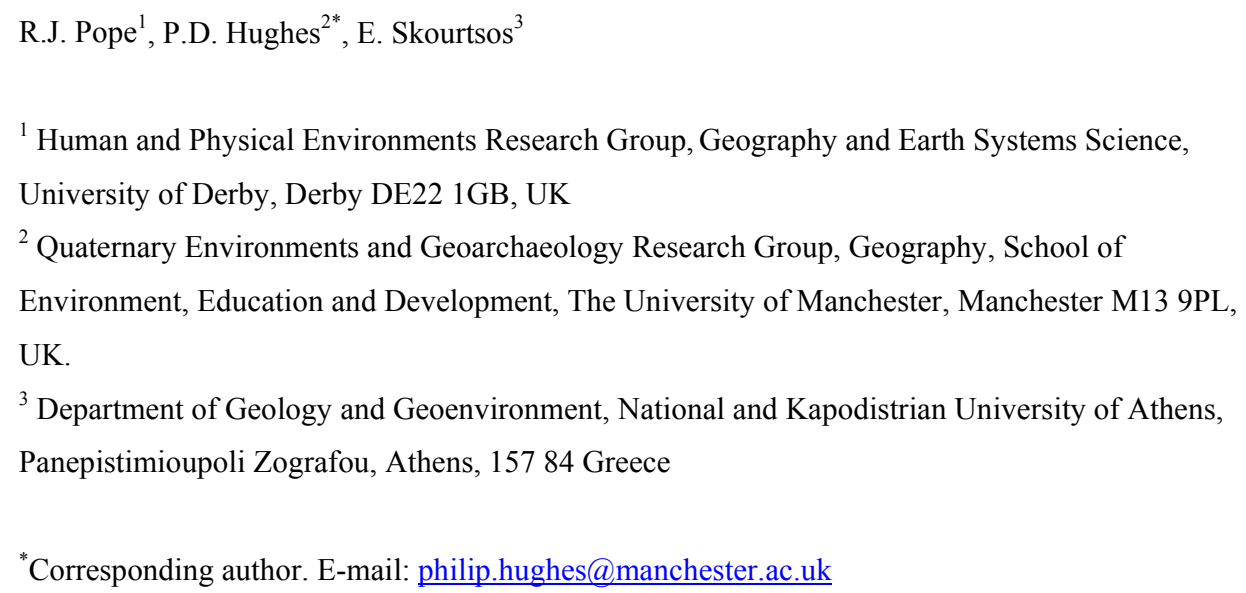

\section{Abstract}

Mount Chelmos in the Peloponnesus was glaciated by a plateau ice field during the most extensive Pleistocene glaciation. Valley glaciers radiated out from an ice field centred over the central plateau of the massif. The largest glaciations are likely to be Middle Pleistocene in age. Smaller valley and cirque glaciers formed later and boulders on the moraines of these glacial phases have been dated using ${ }^{36} \mathrm{Cl}$ terrestrial cosmogenic nuclide exposure dating. These ages indicate a Late Pleistocene age with glacier advance/stabilisation at 40-30 ka, glacier retreat at 23-21 ka and advance/stabilisation at 13-10 ka. This indicates that the glacier maximum of the last cold stage occurred during Marine Isotope Stage (MIS) 3, several thousand years before the global Last Glacial Maximum (LGM; MIS 2). The last phase of moraine building occurred at the end of the Pleistocene, possibly during the Younger Dryas.

\section{Introduction}

The mountains of Greece were glaciated on multiple occasions during the Middle and Late Pleistocene (Woodward and Hughes, 2011). Glaciated terrains have been identified on Mount Olympus in the east (Smith et al., 1997) and throughout the Pindus Mountains (e.g. Sestini, 1933; Mistardis, 1952; Pechoux, 1970; Messerli, 1967; Hagedorn, 1969; Palmentola et al., 1990; Mastronuzzi et al., 1994; Boenzi and Palmentola, 1997; Woodward et al., 2004; Woodward and Hughes, 2011). On Mount Tymphi in NW Greece, different generations of moraines have been dated and assigned to at least three separate cold stages: the Skamnellian Stage (Marine Isotope Stage [MIS] 12); the Vlasian Stage (MIS 6), and; the Tymphian Stage (MIS 5d-2) (Hughes et al., 2006a). 
Moraines have been identified in mountains as far south as the Peloponnesus (Hagedorn, 1969; Mastronuzzi et al., 1994; Pope, 2013; Bathrellos et al. 2014) and also Crete (Fabre and Maire 1983; Bathrellos et al., 2014). In the Peloponnesus several different mountain areas display evidence of extensive glaciation (e.g. Taygetos, Chelmos/Aroania, Ziria/Kyllini, and Erimanthos). However, until now the geochronology and palaeoclimatic significance of these glacial features has remained unexplored. The mountains of the Peloponnesus are strategically important for understanding the relationship between glaciers and climate because of their position at the tip of the Balkan Peninsula. It is well established that glaciers have a close relationship with climate (e.g. Ohmura et al., 1992; Hughes and Braithwaite, 2008) and temporally-constrained glacier-climate reconstructions from the Peloponnesus will provide interesting comparisons with not only other glacial records in the Mediterranean region (e.g. Hughes et al., 2006b), but also with other records of environmental change.

Most glacial records in Greece and the western Balkans have been dated using U-series (Hughes et al. 2006a, 2010, 2011a) which provides a minimum-age for the glacial deposits by dating secondary carbonates. These secondary carbonates can form sometime after the formation of the host moraines and this limits the precision of this particular technique with respect to obtaining the age of the host moraine. Unlike U-series dating, cosmogenic nuclide analyses have the potential to obtain a direct age for a moraine surface and thus provide a more precise geochronology for the Late Pleistocene glaciations of Greece, as has been achieved in neighbouring Turkey (Akçar et al. 2016; Çiner et al. 2016; Sarıkaya et al., 2016). On Mount Olympus in northeastern Greece, Manz (1998) was one of the first to date glacial surfaces in the Mediterranean mountains using ${ }^{36} \mathrm{Cl}$ exposure dating. However, there is considerable scatter in this dataset and interpreting the significance of these pioneering exposure ages is difficult and this issue is discussed in Woodward et al. (2004) and Woodward and Hughes (2011).

The timing of glacier advances during the last glacial cycle shows significant variation around the world. Hughes et al. (2013) showed that many glaciers reached their maximum extents not at the global last glacial maximum (LGM; 27-23 ka, Hughes and Gibbard 2015) in MIS 2 but earlier, during MIS 3, 4 and even 5. In the Mediterranean mountains recent papers have revealed a similar story. In the Pyrenees the largest glaciers of the Late Pleistocene appear to date from early in the last glacial cycle, possibly as early as MIS 5 (Pallàs et al., 2010; Delmas et al., 2011). Evidence from the Cantabrian Mountains of northern Spain suggests that glaciers reached their maximum Late Pleistocene extent during MIS 3 or earlier (Jiménez-Sanchez and Farias Arquer, 2002; Moreno et al., 2010; Serrano et al., 2012; 2016; Nieuwendam et al. 2016) whereas evidence from other areas further south, such as the Sanabria, Sierra de Gredos and Serra de Guadarrama, suggests that the most 
significant advance occurred during MIS 2 close to the global LGM (e.g. Palacios et al. 2011; 2012; Rodríguez-Rodríguez et al. 2014). In Corsica, the LGM is clearly represented as the largest advance of the last cold stage (Kuhlemann et al., 2008) and so too directly to the north in the Maritime Alps of Italy (Federici et al., 2012). A similar pattern is also found in the Italian Apennines, although here the local glacier maximum occurred slightly earlier than the global LGM, between 32 and $27 \mathrm{ka}$ (Giraudi 2012). In northern Greece, a similar age was given for the maximum extent of Late Pleistocene glaciers based on correlations between dated fluvial deposits and upstream glaciation (Hughes et al., 2006c). In Turkey, there is also now evidence for a pre-LGM advance with glaciers reaching their maximum positions by $35.1 \pm 2.5$. ka on Mount Akdağ in the southern part of the Taurus range (Sarıkaya et al., 2014).

In many places the highest cirque moraines are assumed to be of Late-glacial age. In the Italian Maritime Alps this has been confirmed using cosmogenic exposure dating and here there is also evidence for a glacier advance during Heinrich Event I as well as the Younger Dryas (Federici et al., 2012; 2008). Elsewhere the timing of Late-glacial advances remains speculative. For example, in northern Greece Hughes et al. (2006d) assumed that the highest un-dated moraines on Mount Smolikas, the highest of the Pindus, formed during the Younger Dryas. This is supported by evidence from Montenegro to the north. Here, U-series dating of secondary carbonate cements in moraines suggest that the last major moraine-building phase of the Late Pleistocene occurred during the Younger Dryas (Hughes and Woodward 2008; Hughes et al., 2010; 2011a). However, elsewhere in the eastern Mediterranean the evidence for Younger Dryas moraines has been elusive, although a recent papers by Çiner et al.(2015) and Sarıkaya and Çiner (2016) provide new evidence of Younger Dryas moraines in Turkey dated using ${ }^{36} \mathrm{Cl}$ exposure dating. In the eastern Balkans, in Kosovo, Younger Dryas moraines have also been dated using cosmogenics $\left({ }^{10} \mathrm{Be}\right)$ (Kuhlemann et al. 2009). Similar findings have also reported from as far east as Ukraine (Rinterknecht et al. 2012). In Greece, whilst the Younger Dryas is represented in cave sediments (Karkanas 2001), diatom records from lake sediments (Wilson et al. 2008) and alluvial fan sediments from the Sparta basin (Pope and Wilkinson, 2006), it is not so clearly represented in pollen records (Bottema 1995; Lawson et al. 2004). Questions therefore remain as to whether or not the Younger Dryas cold interval is represented by glaciers in the mountains of Greece, and also what the presence or absence of glaciers tells us about climate at this time.

The aim of this project is to establish the extent, timing and palaeoclimatic significance of Late Pleistocene glaciations in the Peloponnesus. The focus is on dating the most recent deglacial history in the highest cirque areas and comparing the deglacial chronologies with other Mediterranean mountains. This paper uses ${ }^{36} \mathrm{Cl}$ analyses to provide exposure ages for the most recent series of moraine surfaces on Mount Chelmos (2355 m a.s.1.) in the northern Peloponnesus, Greece (Fig. 1). 
Glacier-climate reconstructions for different glacier phases are then compared with evidence from other glaciated Mediterranean mountains in order to establish former climatic patterns for the last glacial cycle. Mount Chelmos represents one of the southernmost glaciated areas of Europe $\left(38^{\circ} \mathrm{N}\right)$, rivalled only by the Sierra Nevada of Spain and Etna, Sicily (although in the latter area any glacial traces have been obscured by volcanic activity). Thus, glacier records in the Peloponnesus provide a unique insight into palaeoclimatic conditions in the Mediterranean, especially for the eastern Mediterranean basin.

\section{Study areas}

Mount Chelmos (also known as Aroania) reaches $2355 \mathrm{~m}$ a.s.l. and is the third highest mountain in the Peloponnesus. The massif forms part of the mountain chain of the External Hellenides and consists of rocks belonging to three distinct tectonic units. The upper one is the Pindos Unit, which occupies both the highest peaks and the southern slopes of the mountain and consists mainly of pelagic limestones and radiolarites of Mesozoic age overlain by a Tertiary clastic sequence (flysch). The Tripolis Unit is the intermediate unit and consists of platform carbonates that are Upper Triassic to Upper Eocene in age overlying a volcanosedimentry sequence, called Tyros Beds. The lower altitude slopes of northeastern Chelmos are built by HP-LT metamorphic rocks of the lowest Phyllites-Quartzites Unit. These units were folded and stacked together during the main alpine orogenesis culminated in the Oligocene and Miocene while subsequent syn-orogenic extension resulted in exhumation of metamorphic rocks (Skourtsos and Kranis, 2009; Skourtsos and Lekkas, 2010). Although, plate movements and orogenesis are still active far away to the west, the Gulf of Corinth, immediately to the north of Mount Chelmos, is a very active and fault-controlled rift with contemporary uplift of the Peloponnesus leading to new faulting (Moretti et al, 2003; Skourtsos and Kranis, 2009; Ford et al, 2013) (Fig. 1). The northern areas of the mountain forms the southern, now inactive, margin of the rift at the hanging wall of which continental Pliocene deposits have been deposited (Skourtson and Kranis, 2009; Ford et al, 2013). Pleistocene and Holocene estimated uplift rates in the northern Peloponnesus are not homogeneous and range from 0.3 $\mathrm{mm} \mathrm{yr}^{-1} 50-60 \mathrm{~km}$ northeast of Mount Chelmos (Collier et al., 1992) to $1.5 \mathrm{~mm} \mathrm{yr}^{-1}$ (Armijo et al., 1996; McNeill et al., 2004; Palyvos et al.,2008) and even higher, 2.9 to $3.5 \mathrm{~mm} \mathrm{yr}^{-1}$, during the Holocene (Pirazzoli, et al., 2004) $20 \mathrm{~km}$ north of Mount Chelmos, and $0.55 \mathrm{~mm} \mathrm{yr}^{-1}$ in the southern Peloponnesus (Mariolakos et al., 1994).

The nearest official climate normal data is available from Patrai (Patras) station ( $3 \mathrm{~m}$ a.s.1.) c. $50 \mathrm{~km}$ NE of Mount Chelmos. The 1961-1990 period at this site recorded a mean annual temperature of $17.9^{\circ} \mathrm{C}$, a mean annual range of $16.7^{\circ} \mathrm{C}$ and mean annual precipitation of $682 \mathrm{~mm}$ (World Meteorological Organisation, 1998). The climate at Kalavryta weather station (731 m a.s.1.), at the 
foot of Mount Chelmos, has recorded a mean annual temperature of $13.6^{\circ} \mathrm{C}$ and mean annual precipitation of $996 \mathrm{~mm}$. In the highest mountain areas annual precipitation must therefore exceed $1000 \mathrm{~mm}$ and is estimated to be in the range $1500-2000 \mathrm{~mm}$ based on the precipitation difference between Patras (3 $\mathrm{m}$ a.s.1.) and Kalavryta (731 $\mathrm{m}$ a.s.1.). Precipitation is strongly seasonal with a wet winter season and an arid summer season, which is typical of Mediterranean climates (Koutsopoulos and Sarlis, 2003). No glaciers survive today on Mount Chelmos, although snow patches have been observed by the authors in late July below the north-facing cliffs near Mavrolimni (Fig. 2).

\section{Methods}

\section{Field methods}

The glacial geomorphology of Mount Chelmos was mapped in the field in July 2010 and July 2011. Place names are based on the 1:50,000 topographic map (Anavasi, 2008). The accuracy of this fieldmapping was aided by high-resolution satellite imagery available in GoogleEarth. Moraine units were identified on the basis of sedimentological and morphological criteria (e.g. clast size, shape, roundness, sediment sorting, surface form) and subdivided on the basis of morphostratigraphy (Hughes, 2010).

Several studies have successfully dated limestone landslide boulders from Marine Isotope Stage (MIS) 2 and later using ${ }^{36} \mathrm{Cl}$ analysis (e.g. van Husen et al. 2007, Ivy-Ochs et al., 2009) although there are few examples where older surfaces have been successfully dated using this technique. However, in other areas of Greece the oldest moraines have been shown to be Middle Pleistocene in age, as old as MIS 12 (Hughes et al. 2006a).Samples were therefore not taken from the lowest moraines on Chelmos because there is a much greater risk of age scatter from these moraines because of exhumation, toppling and erosion/weathering of the boulder surfaces. Instead, we targeted the highest moraines (and therefore stratigraphically youngest) in selected valleys and sampled seven glacial boulders using a hammer and chisel (Table 1). All of the samples were from fine-grained crystalline limestones. All samples were taken from the tops of boulders at least $50 \mathrm{~cm}$ away from any edges in order to minimise edge effects which are most significant for terrestrial cosmogenic nuclides such as ${ }^{36} \mathrm{Cl}$, which is produced in part through thermal neutron capture (Gosse and Phillips 2001).

\section{Laboratory analysis and geochronological calculations}

Rock samples were crushed and sieved. The $<63 \mu \mathrm{m}$ fraction was mixed with resin and pressed to form a powder pellet for XRF analysis of the bulk rock (major elements \% and some trace elements ppm) s. Some trace elements (Li, B, Sm, Gd, Th, U) were also determined using ICP-MS for higher 
precision (ppm). The 250-500 $\mu \mathrm{m}$ fractions were sent to PRIME Lab at Purdue University for ${ }^{36} \mathrm{Cl}$ processing and accelerator mass spectrometry (AMS) measurement.

The sample data and the results of the AMS and geochemical analyses from the rock samples (Tables 1 to 3) were used to calculate exposure ages using the excel calculator of Schimmelpfennig et al. (2009). This calculator has been used to provide ages for limestone samples as well as basalt samples. Examples of its successful use to date carbonate surfaces include Le Dortz et al. (2011), Sadier et al. (2012) and Ryb et al. (2014). The default production rate for the spallation of Ca in Schimmelpfennig et al. (2009) is from Stone et al. (1996) at $48.8 \pm 3.4$ atoms ${ }^{36} \mathrm{Cl}(\mathrm{g} \mathrm{Ca})^{-1} \mathrm{a}^{-1}$. Other values for the production rate for $\mathrm{Ca}$ are $42.8 \pm 4.8$ atoms ${ }^{36} \mathrm{Cl}(\mathrm{g} \mathrm{Ca})^{-1} \mathrm{a}^{-1}$ from Schimmelpfenning et al. (2011), $56.0 \pm 2.2$ atoms ${ }^{36} \mathrm{Cl}(\mathrm{g} \mathrm{Ca})^{-1} \mathrm{a}^{-1}$ from Marrero (2012) and $57 \pm 5$ atoms ${ }^{36} \mathrm{Cl}(\mathrm{g} \mathrm{Ca})^{-1} \mathrm{a}^{-1}$ from Licciardi et al. (2008). However, in all three of these papers the production rates are derived from mixed rock compositions (rocks with both $\mathrm{Ca}$ and K present) whereas Stone et al. (1996) is derived from limestones (with just Ca present). Thus, the production rate of Stone et al. (1996) is likely to be the most reliable for limestone samples.

Bulk rock densities were measured in the laboratory using a simple water displacement method and were c. 2.5 to $2.7 \mathrm{~g} \mathrm{~cm}^{-3}$, which is consistent with most limestones. Scaling factors for the production of nucleonic and muonic production as a function of elevation, latitude and temporal variations were calculated following Stone (2000). Correction factors for shielding of a sample of arbitrary orientation by surrounding topography were calculated in the CRONUS on-line calculator (Version 1.1. March, 2006. Written by Greg Balco; http://hess.ess.washington.edu/math/general/skyline input.php). All samples were taken away from edges from the top surface of boulders that were at least $1 \mathrm{~m}$ high. Consequently, correction factors for geometry effects on spallogenic production and for snow shielding for spallogenic production were not necessary and given a value of 1 in the excel calculator. A value of $177 \mathrm{~g} \mathrm{~cm}^{-2}$ was used for the effective fast neutron attenuation coefficient. The estimated ${ }^{36} \mathrm{Cl}$ concentration from inheritance was assumed to be zero. The measured ${ }^{36} \mathrm{Cl}$ concentration in the sample was reported by PRIME Lab. Inputs for exposure duration, formation age of rock for radiogenic correction, and erosion rate were left blank in the calculator as we assume that surfaces have undergone minimal surface loss since glaciation.

\section{Glacier reconstructions}

The combination of the geomorphological mapping and the ${ }^{36} \mathrm{Cl}$ exposure ages will provide the basis for temporally-constrained glacier-climate reconstructions. Former glaciers were reconstructed based on limits defined by moraine crests (where present) or the distal limits of glacial deposits. The upper limits of the former glaciers were constrained by cirque morphology and the altitude of the cirque 
headwall. In the absence of a cirque then other criteria were used to constrain upper ice limits, such as the upper distribution of ice-moulded bedrock, perched boulders and periglacial trimlines. Glacier surface profiles for the most extensive ice cap phase were reconstructed using an iterative flowline model (Benn and Hulton, 2010). This approach takes into account topographical irregularity below the former ice caps. A basal shear stress of 50-100 kPa was applied based on a range of measurements known to occur in valley glaciers (see Vieira 2008, p. 197 for further references). This produced a range of potential surface altitudes for the former ice masses and the most suitable end of this range (50 or $100 \mathrm{kPa}$ ) was constrained using geomorphological evidence of glacial erosion and deposition at certain altitudes. For the smaller cirque and valley glacier phases glaciers were simply reconstructed using the geomorphological evidence (moraine positions primarily) and tested for plausibility by calculating the basal shear stress. The shape and distribution of surface contours and ice margins (where not constrained by geomorphology) were then tuned until shears stress values in the range 50$100 \mathrm{kPa}$ were obtained.

Equilibrium line altitudes (ELAs) are reported in this paper using an accumulation area ratio (AAR) of 0.6. This is because this value was used to reconstruct the ELAs on the glaciers in NW Greece on Mount Tymphi and Mount Smolikas (Hughes et al. 2006c; 2006d; 2007a). However, in order to make comparisons with glaciers around the Mediterranean, a range of potential ELAs were also estimated using a range of AARs from 0 to 1 . For example, the ELAs of different generations of glaciers on Mount Orjen, Montenegro, were calculated using AARs of 0.5, 0.6 and 0.8 (Hughes et al 2010). These examples were based on the AAR with the lowest standard deviation in a population ofglaciers of the same age (cf. Osmaston, 2002; Hughes et al., 2010). This approach assumes that for a sample of similar types of glaciers on the same mountain, the controls on ELA position will be similar, producing comparable patterns in glacier hypsometry. Often, glacier snouts may be expected to have the greatest variation in altitude (with an AAR of 1) because glacier front positions depend on the overall hypsometry of the glacier above it. Conversely, glacier sources (with an AAR of 0) are often less variable on a single radially-glaciated mountain, such as Chelmos, because peak altitudes across the glacier sample tend to be similar. This relationship between snout and source altitudes across a glacier sample tends to produce an asymmetrical U-shaped relationship for populations of valley and cirque glaciers (Osmaston, 2000, Fig. 9.4.7, p. 182). The standard deviation of AAR approach is simply a tool that can help describe the former hypsometry of glaciers and a variety of patterns may emerge depending on the geometry of the former glaciers. Different AARs may be suitable for different types of glaciers, and it is known that the ELAs of ice caps, valley glaciers and cirque glaciers correspond to different AARs (e.g. Leonard 1984) as do debris-covered versus clean glaciers (Clark et al., 1994). Ultimately, the user must still rely on empirical observations of the relationship between AARs and ELAs and be aware of potentially wide variability for palaeo glaciers. 
It is known that Mount Chelmos is situated in one of the most tectonically active parts of Greece, just south of the Gulf of Corinth. The potential for tectonic movements is therefore great. Comparing ELAs with other parts of Greece (e.g. Hughes et al. 2006c; 2007a) is problematic given the uncertainties in knowing the uplift history of the area. This issue is explored further in the Discussion.

\section{Results}

\section{Glacial geomorphology}

The extent and distribution of glacial landforms on Mount Chelmos is illustrated in Fig. 2. The characteristics of the evidence for glaciation are described below for the five main valleys that drain the massif.

\section{(1) Spanolakos Valley}

The Spanolakos valley drains the northwestern flank of Chelmos. A series of sediment landforms are present in this valley and these are described then interpreted in morphostratigraphical order from lower to upper valley.

\section{Unit 1}

\section{Description:}

The lower slopes, below c. 1600-1700 m are characterised by thick accumulations of thick accumulations of gravels separated by occasional sandy interbeds. These are exposed by the modern river channel and reach thicknesses of $>30 \mathrm{~m}$. The sediment spreads out from the apex (at c. 1600$1700 \mathrm{~m}$ ) to reach a width of nearly $2 \mathrm{~km}$ in the lower parts at c. 1200-1300 m near the village of Kato Lousi. Between 1600-1700 m cemented gravels and sands are topped by numerous large perched boulders (Fig. 3). These have diameters of $>1 \mathrm{~m}$ and are subangular to subrounded.

\section{Interpretation:}

The large area of bedded gravels and sands that reach down to Kato Lousi is interpreted as a stacked sequence of glaciofluvial fans. The perched boulders in the upper part of the fan are interpreted as glacial in origin and are similar to deposits found in several other valleys (see below). The boulders do not form clear moraines but are instead scattered over wide areas. The down-valley limit of these boulders is mapped as a boulder limit in Fig. 2 and is interpreted as the approximate down-valley extent of the largest former glacier in this valley. These glacial deposits are denoted as stratigraphical unit 1 in Fig. 2.

Unit 2 


\section{Description:}

At c. 1900-2050 m a very clear arcuate ridge is present (Fig. 4). Subrounded and subangular boulders (many $>1 \mathrm{~m}$ in diameter) are present on the surface of this feature. The ridge is exposed near the modern river channel and this reveals $>10 \mathrm{~m}$ thickness of diamicton, characterised by subrounded/subangular boulders supported by a pale sandy-silt matrix (clast density: c. $20 \%$ ). The sediments are cemented in several places and cemented horizons are present.

\section{Interpretation:}

The sediment ridge is mapped as a moraine ridge marking the termino-lateral positions of a former valley glacier. This was also the interpretation of Mastronuzzi et al. (1994, their Fig. 4). These glacial deposits are denoted as stratigraphical unit 2 in Fig. 2.

\section{Description:}

Between c. 1900-2000 m the valley floor is filled with boulders, some of which reach several metres in diameter. This sediment pile forms a subdued ridge that bounds the northern side of the main river for c. $250 \mathrm{~m}$ with a width of c. $75 \mathrm{~m}$ Subrounded and subangular boulders (many $>1 \mathrm{~m}$ in diameter) are present on the surface of this feature.

\section{Interpretation:}

The sediment ridge is mapped as a moraine/glacial boulders (indistinct) in Fig. 2 marking the terminus of a former cirque glacier. This small glacier would have been banked up against the unnamed peak with spot height $2145 \mathrm{~m}$ whose northern cliffs mark the headwall of this cirque. These glacial deposits are denoted as stratigraphical unit 3 in Fig. 2.

\section{(2) Laghada valley (Strogilolaka \& Kato Kambos)}

The Laghada valley also drains the western slopes of Chelmos and is the southern neighbouring valley of the Spanolakos (Fig. 2). However, the Laghada valley is very different in profile to the Spanolakos. The Laghada has a very steep middle profile (from 1400-2000 m) and forms a deeply incised valley for the entire middle and lower reaches (from 1100-2000). The upper valley (above $2000 \mathrm{~m}$ ) is perched with a gentle gradient. This valley morphometry means that the preservation potential for Pleistocene deposits in the middle and lower Laghada is very limited. All of the evidence for glaciation is restricted to the highest reaches where the Laghada drains two elevated pastures near the shepherd pastures at Strogilolaka and Kato Kambos (Fig. 2).

\section{Unit 1}


Description:

At Strogilolaka large subrounded and subangular boulders are scattered over wide areas between altitudes 1900 and $2100 \mathrm{~m}$ immediately below and west of the bulldozed track that traverses the western flank of Chelmos. In several places these lie on top of diamicton ridges (boulders in a silt matrix) that are several metres high. These diamicton deposits have been heavily incised by modern stream activity and are poorly preserved. The eastern side of this area is bounded by steep rocky slopes until the crest of the watershed with angular debris present.

In the southern fork of the Strogilolaka valley leading up towards Kato Kambos occasional boulders can be seen perched in the steep valley. However, the river has a very steep course, which limits preservation of unconsolidated deposits. In addition access is difficult to this area and observations were limited.

\section{Interpretation:}

These are interpreted as glacial deposits and correlated with the Unit 1 deposits in the Spanokakkos valley. No other glacial deposits are present up-valley of this area, only talus and rock slopes failure deposits which form some prominent ridges of large angular boulders below the west-facing cliffs which are traversed by the bulldozed track immediately up-valley of the Strogoilaka moraines.

A glacial limit is also tentatively mapped in the southern fork of the Strogilolaka valley which lead up towards Kato Kambos, although moraines are not clearly preserved.

Unit 2

\section{Description:}

A sediment ridge with large subrounded and subangular boulders on its surface is situated on the northern side of the valley immediately west of Kato Kambos (Fig. 2) between c. 2050 and 2140 m. The boulders have diameters of 1-3 m and many are present along the ridge crest. Boulders are also present on the south-side of the modern river channel (again between c. 2050 and $2140 \mathrm{~m}$ ) although these are isolated and scattered and do not form a discernible ridge crest.

\section{Interpretation:}

The sediment ridge in the lower Kato Kambos clearly resembles a moraine ridge and is interpreted as a latero-frontal moraine of a former valley glacier. The lower limit of boulders in this area on both the north and south side of the modern river channel suggests a down-valley altitude of c. $2050 \mathrm{~m}$ for this glacier, perched just above the steep and deeply incised Lagadha valley. These moraines and glacial boulders are correlated with unit 2 in other valleys on the basis of altitudinal position. 
400

401

Two boulders from the outermost latero-frontal moraine were sampled for ${ }^{36} \mathrm{Cl}$ analysis, both from the crest at c. $2120 \mathrm{~m}$ altitude. The boulders are shown in Fig. 5 with sample details and exposure age results shown in Tables 1, 2 and 3. These samples yielded exposure ages $39.6 \pm 3.0$ and $30.4 \pm 2.2 \mathrm{ka}$.

\section{Unit 3}

\section{Description:}

A very clear arcuate sediment ridge is present with a crest situated at c. $2140 \mathrm{~m}$ with numerous large ( $>2-3 \mathrm{~m}$ ) subrounded boulders scattered on the surface is present bounding the basin of Kato Kambos which is situated below the northern cliffs of Profitis Ilias $(2282 \mathrm{~m})$. The ridge crest is $>10 \mathrm{~m}$ above the floor of the basin and almost completely closes the NW outlet of the basin with only a small stream cutting through the ridge. The floor of the Kato Kambos basin contains a level area of marshland. A subdued sediment ridge with surface boulders is also present in the eastern part of the basin in a small adjacent hollow (Fig. 2).

\section{Interpretation:}

Kato Kambos is a glaciokarst cirque basin. The backwall cliffs of Profitas Ilias provided the sources of the former glacier. The basin is over-deepened and is similar in appearance to glaciokarst basins observed in northern Greece (Hughes et al. 2007b) and Montenegro (Hughes et al. 2011a). The cirque at Kato Kambos (Fig. 6) is one of the best-developed cirques on Chelmos, alongside the cirques at the head of the Chaliki valley below spot height $2318 \mathrm{~m}$, at the head of the Xerokambos valley, and below spot height $2145 \mathrm{~m}$ at the head of the Spanolakkos valley; in other areas cirques are poorlydefined or not present at all. The sediment ridge is interpreted as an arcuate moraine and represents one of the best and clearest examples of a cirque moraine in Greece. The marshland in the centre of the cirque basin hints at the presence of potential lake and a break of slope encirculing the basin (c. 5$10 \mathrm{~m}$ above the basin floor) may indicate a former lake shoreline. A subdued moraine crest is also present in the eastern basin (Fig. 2) and this may be associated with glacier retreat as the cirque glacier would have split into two cirque basins. These moraines represent the highest moraines in the Strogiolakkos valley and are correlated with $\underline{\text { Unit } 3}$ moraines in other valleys.

A large boulder (diameter $>3 \mathrm{~m}$, height $>2 \mathrm{~m}$ ) on the crest of the moraine was sampled for ${ }^{36} \mathrm{Cl}$ analysis (Fig. 7). The sample details and exposure age results are shown in Table 1, 2 and 3. This sample yielded an exposure age of $12.6 \pm 0.9 \mathrm{ka}(\mathrm{CH} 10)$. Another large boulder (diameter $>2 \mathrm{~m}$, height $>1 \mathrm{~m}$ ), just 5 metres distance from $\mathrm{CH} 10$ was also sampled and this yielded an exposure age of $10.2 \pm 0.7 \mathrm{ka}$.

(3) Chaliki Valley 
The Chaliki valley drains the southern flank of Chelmos immediately south of the steep southern rock face of Psili Korfi (Fig. 2). The lower valley is characterised by large spreads of gravel and sands and a braided river system leading to alluvial terraces near the village of Planitero. Glacial deposits are restricted to the higher reaches and these are described below.

\section{Unit 1}

\section{Description:}

Diamicton deposits with large subrounded boulders within a silt matrix are exposed in the modern river channel at an altitude of c. $1300 \mathrm{~m}$ (Fig. 8) immediately to the north of Magherou, a southeastern spur of Profitis Illias. The valley is very steep and narrow and these deposits are found plastered against the valley sides, often well above the modern river channel but have little or no surface form. Some boulders display evidence of striae.

\section{Interpretation:}

The diamicton deposits are interpreted as glacial in origin, formed by a valley glacier that extended down this valley. The poorly sorted materials and presence of a fine silt matrix along with striated boulder clasts is the main basis of this interpretation. The lowermost presence of these deposits is taken as an approximate limit of glaciation. However, the steepness of the catchment means that preservation potential is low. These glacial deposits are correlated with stratigraphical unit 1 .

\section{Unit 2}

\section{Description:}

Mounds of diamicton deposits with large $(>1 \mathrm{~m})$ subrounded and subangular boulders in a silt matrix are situated above a break in slope of the main river channel between altitudes of c. $1550-1650 \mathrm{~m}$. The valley becomes more open in this area and the river bed widens considerably forming a wide braid plain. The diamicton deposits are exposed by numerous smaller tributary streams in this area and a concentration of scattered and perched subrounded and subangular boulders occurs throughout this area. Similar boulder diamictons are also exposed in the centre of the valley on an interfluve separating two stream channels between 1680 and 1900 m (see Fig. 2).

\section{Interpretation:}

The concentration of diamicton deposits and perched boulders in this area are interpreted as eroded end moraines. These moraines are correlated with $\underline{\text { Unit } 2}$ moraines found in other valleys.

Unit 3 


\section{Description:}

Clear sediment ridges are present in the basin below the SE face of the summit spot height $2318 \mathrm{~m}$ marked on topographic maps (Anavasi, 2008) and bound an area of concentrated boulder debris (Fig. 9). The sediments ridges reach an amplitude of nearly $10 \mathrm{~m}$ whilst boulders within these limits reach diameters of $>5 \mathrm{~m}$ and are an admixture of angular, subangular and subrounded boulders.

\section{Interpretation:}

The sediment ridges are interpreted as the end moraines of a small cirque glacier. The concentrated boulder debris inside of these moraines is a mixture of subglacial and supraglacial debris as well as talus debris. Whilst the cirque is clear as an armchair-shaped bowl, it is weakly incised (Fig. 9).

(4) Neraidhorachi

The Neraidhorachi area represents the central plateau area of Chelmos and a major valley drains northeastwards towards the village of Mesorroughi. The valley is the deepest and widest of all the valleys draining Chelmos. The Styx waterfall, named after the river in ancient Greek mythology and today part of the Mavroneri River, occurs in the upper valley area below the Neraidhorachi plateau (Mayor and Hayes 2011).

Unit 1

\section{Description:}

Diamicton deposits and spreads of perched subrounded and subangular boulders are present in the forests and reach below an altitude of $1200 \mathrm{~m}$. These deposits form extended ridges on both side of the modern river valley that drains towards Mesorroughi (Fig. 2). The sediment ridge is most clearly expressed between c. 1180-1450 $\mathrm{m}$ on the northern side and is largely covered in forest. However, surface boulders are clearly visible in small clearings and revealed in section by forest roads. Interpretation:

The diamictons and boulders have the characteristics of glacial deposits in that they are poorly sorted, subrounded and subangular and form ridges on both sides of the valley. The sediment ridges resemble latero-frontal moraines and are consistent with a large outlet glacier draining from the central plateau area of Neraidhorachi. The valley morphology in the area of the Styx waterfall also resembles an over-steepened U-shaped valley indicating that a glacier must have extended down-valley far beyond this locality.

Unit 2 


\section{Description:}

Mounds of subrounded boulder-rich diamicton are present at several positions in the valley northeast of Neraidhorachi and are best preserved where the long profile of the valley becomes less steep, such as at c. 1600,1800, 2000, 2100 and $2250 \mathrm{~m}$. These successive piles of diamicton and boulder material are largely shapeless, although form irregular mounds and occasionally ridge-like forms, the latter especially so in the higher areas. For example, around Epano Kambos, an arcuate sediment ridge encloses the uppermost basin at c. $2250 \mathrm{~m}$.

\section{Interpretation:}

The diamicton mounds and boulder accumulations are interpreted as moraines of a former valley glacier. The moraine unit spans the valley from 2250-1600 $\mathrm{m}$ and is separated from Unit 1 because of the large distance and altitude between these and the lowermost glacial deposits in this valley, which are $2 \mathrm{~km}$ and more than $400 \mathrm{~m}$ in altitude down-valley. The multiple moraines, situated at the breaks in the valley profile, are consistent with terminal and recessional positions of the former glacier that occupied this valley. The moraines are grouped together morphostratigraphically with the lower limit of these deposits at $1600 \mathrm{~m}$ taken as the lower limit of the glacier. The glacier occupied a large Ushaped valley that was inherited from the larger glacier associated with the Unit 1 moraines $2 \mathrm{~km}$ down-valley. The successive moraine piles at 1800, 2000, 2100 and 2250m are interpreted as recessional or stand-still moraines as the glacier retreated up-valley. These moraines are formed of substantial accumulations of sediment ( $>10 \mathrm{~m}$ thickness) and are incised by the modern stream channel. The uppermost arcuate moraine at Epano Kambos is very clearly defined and could be classified as a separate morphostratigraphical unit and correlated with Unit 3 moraines in other valleys. However, the moraine has a similar surface exposure age to lower moraines in this area - see below and Fig. 2. Furthermore, the basin headwall is less steep than in other areas occupied by Unit 3 moraines elsewhere where a steep cirque backwall always exists. The basin in Epano Kambos, whilst cirque-like, lacks a steep backwall, and is therefore not mapped as a cirque in Fig. 2 despite the presence of a moraine.

Three boulders from the uppermost moraine mounds ( $>2200 \mathrm{~m}$ a.s.1.) in this assemblage were sampled for ${ }^{36} \mathrm{Cl}$ analysis, two from the crest of a broad moraine ridge on the west side of the valley and another from the crest of the uppermost arcuate moraine. The sample details and exposure age results shown in Tables 1, 2 and 3. These samples yielded exposure ages of $21.2 \pm 1.6,21.6 \pm 1.6$ and $22.9 \pm 1.6 \mathrm{ka}$, respectively. These ages are indistinguishable and overlap within error and indicate that ice must have retreated rapidly at 23-21 ka in the highest parts of this valley ( $>2200 \mathrm{~m}$ a.s.1.). The lowest moraines of this unit, which were associated with a glacier that reached down to $1600 \mathrm{~m}$ a.s.l. must pre-date the exposure ages from the uppermost moraines. 
(5) Xerokambos

The Xerokambos valley drains northwards from Chelmos. The valley contains the Kalavryta ski centre and is the easiest valley to access. There has been considerable reworking of surface deposits in this valley due to construction activities.

Unit 1

\section{Description:}

Scattered subrounded boulders are present throughout the area of Xerokambos. A thin layer of diamicton with cobbles and boulders lodged within the deposits is present also. The Ski Centre and adjacent car park has destroyed much of the evidence in the lower valley area. Mastronuzzi et al. (1994, p. 81) recognised that "a veneer of morainic deposits" occurs in the valley floor down as far as the ski centre. The observations made above of large subrounded boulders and thin diamicton deposits supports their interpretation that a glacier once reached as far as the Ski Centre buildings and car park. There is no clear moraine limit since much of the ground has been disturbed but this area is likely to define the lower limit of the most extensive former glacier that has existed in this valley.

Unit 2

536 smoothed and the valley headwall is distinctly concave.

\section{Interpretation:}

The arcuate ridge of boulder diamicton is interpreted as an end moraine of a former cirque glacier that emanated from the northwestern cirque of the highest peak of Chelmos. This clear glacial feature was also recognised by Mastronuzzi et al. (1994). The smoothed bedrock up-valley of this ridge was interpreted as roche moutonées by these authors and the field evidence does suggest ice moulding, although there has been considerable reshaping of the floor of this cirque in recent years in developing ski runs. 
Unit 3

\section{Description:}

A small accumulation of boulders occurs on the west side of the uppermost cirque at c. $2180 \mathrm{~m}$ altitude. The evidence from the centre of the valley has been obliterated by bulldozing of a ski run. The uppermost cirque is very enclosed, much more so than the lower parts of the valley.

\section{Interpretation:}

The tight cirque basin at the head of Xerokampos is likely to have hosted a small cirque glacier. The small accumulation of boulders on the west side of the valley, which are interpreted as moraines, supports this hypothesis. This moraine unit is correlated with Unit 3 moraines, the highest present in other valleys.

(6) Watersheds and interfluves

This section describes the geomorphology of the highests plateaus and ridges that separate the various valleys described above. This is important for determining whether glaciers were restricted to their valleys or submerged the landscape in the form of an ice cap or plateau ice field.

\section{Description:}

Large areas of bare smooth bedrock occur to the north of Psili Korfi including the entire western flank of spot height $2253 \mathrm{~m}$ (Fig. 2). Large subrounded and sub angular boulders are perched on some interfluves, including one very large boulder ( $>2 \mathrm{~m}$ diameter) just south of the summit of spot height 2253. Perched boulders are also present on the ridge col west of Psili Korfi summit. Bare bedrock knolls are also present in the Neraidhorachi area. A prominent knoll occurs close to a shepherd settlement in Epano Kambos, just east of the track leading to the astronomical observatory.

\section{Interpretation:}

The large areas of bare smooth bedrock are interpreted as ice moulded bedrock. The large subrounded and subangular boulders that are found perched on interfluves are interpreted as glacially-transported boulders. The source of these boulders is likely to be the ridge between Psili Korfi and spot height $2253 \mathrm{~m}$. These observations have important implications for the configuration of ice masses on Chelmos, since it means that ice completely submerged the central plateau area covering and eroding interfluves and also transporting boulders at high levels. However, the ice mass was constrained and hemmed in by the highest summits that surround the plateau.

\section{Summary of the geomorphological evidence}


The valleys of Chelmos all display clear evidence of multiple glacial phases in the form of moraines. There are three morphostratigraphical glacial (moraine) units in the valleys and cirques of Chelmos (Table 4). Each of these morphostratigraphical units represents suites of moraines. In other words, the moraine units are diachronous with outer moraines and inner (recessional) moraines grouped as part of the same stratigraphical unit. The upper valley source areas are not always defined by cirques. The clearest cirques are present at the heads of the Laghada valley (at Kato Kambos), the Chaliki valley,the northeastern valley draining Neraidhorachi (at Epano Kambos) and at the head of the valley above Xerokambos (above the ski centre) (see Fig. 2). There is also evidence of ice moulding and boulder transport at high-elevations close to watersheds and this indicates that ice must have submerged the central plateau areas of Chelmos with an ice cap centred over the Neraidhorachi area which marks the central plateau of Chelmos. This explains the apparent paradox that there are only four clear cirques yet extensive moraine successions in six valleys that radiate from the centre of the massif (see Fig. 2 and Fig. 10). The geomorphology is therefore crucial for the correct reconstruction of former ice masses corresponding with the different morphostratigraphical moraine units. This is the focus of the next section.

\section{Glacier reconstructions}

The largest, Phase I, glaciation was characterised by a contiguous ice cap covering an area of 9.74 $\mathrm{km}^{2}$ that was radially drained by six outlet valley glaciers (Fig. 10). The longest outlet glaciers were the Chaliki and Neraidhorachi glaciers which reached c. $3.5 \mathrm{~km}$ in length. The shortest outlet glacier was the Strogilolaka glacier which had a length of c. $1.5 \mathrm{~km}$. Ice thickness reached c. $500 \mathrm{~m}$ in the Neraidhorachi valley north and northeast of Mavrolimni (Figs 1 and 2). The average ELA (assuming an AAR of 0.6) of the six outlet glaciers was $1984 \mathrm{~m}$ a.s.l. There was no asymmetrical U-shaped relationship between the standard deviation of altitude and AAR (e.g. Osmaston 2002). Instead there was a positive relationship between AAR and standard deviation of altitude with the greatest standard deviations for higher AARs (Table 5).

The Phase II glaciation was characterised by cirque and valley glaciers. A transect glacier covered the watershed between Profitas Ilias and Psili Korfi with valley glaciers descending east and west. The Phase II glaciers covered an area of $4.445 \mathrm{~km}^{2}$. The smallest glacier was the Spanolakos glacier $\left(0.365 \mathrm{~km}^{2}\right)$ whilst the largest was the Neraidhorachi $\left(1.623 \mathrm{~km}^{2}\right)$. The average ELA of the five glaciers using an AAR of 0.6 was $1986 \mathrm{~m}$ a.s.l. The apparent paradoxical situation of much smaller glaciers than Phase I but with similar ELAs is because of effects of the hypsometry of the Phase I ice field in increasing the area of ice at higher elevations. This is examined further in the discussion. 
Again, there was no asymmetrical U-shaped relationship between the standard deviation of altitude and AAR and the pattern was similar (but with smaller standard deviations) to the Phase I glaciers (Table 5).

The Phase III glaciers were small cirque glaciers. The four glaciers covered a total area of just 0.732 $\mathrm{km}^{2}$, with the largest glacier in the Kato Kambos cirques $\left(0.417 \mathrm{~km}^{2}\right)$ and the smallest in the Xerokambos cirque $\left(0.050 \mathrm{~km}^{2}\right)$. These glaciers had an average ELA of $2114 \mathrm{~m}$ a.s.l. when using an AAR of 0.6. Again, there was positive relationship between the standard deviation of altitude and AARs of 0.4 to 0.8 (Table 5). In this sample of glaciers there was little variation in standard deviations across AARs.

\section{Discussion}

Mount Chelmos displays clear evidence of glaciation. Moraines are present down to $1200 \mathrm{~m}$ a.s.l. in five valleys draining radially from the central plateau area. The most extensive glaciation was characterised by an ice cap which submerged the highest areas with ice radiating outwards from a central ice dome located in the Neraidhorachi area. The resulting effects of ice cap glaciation are exhibited by evidence of ice moulding and glacier transport at high elevations, a radial glacial valley system. The largest and deepest glaciated valley was formed by a glacier that extended c. $4 \mathrm{~km}$ northeastwards from the central plateau (the length of the former glacier form the ice cap centre was c. $3.5 \mathrm{~km})$.

The largest ice cap glaciation remains undated. Based on correlations with northern Greece and Montenegro (Hughes et al. 2006a; 2010; 2011a) it is likely that the largest glaciation is Middle Pleistocene in age (Skamnellian Stage/MIS 12 and Vlasian Stage/MIS 6). On Mount Chelmos the largest glacial phase is represented by a single morphostratigraphical unit (stratigraphical unit 1 in Fig. 1). However, it is possible that more than one glaciation is represented by this unit. At present it is not possible to separate out multiple moraine units that could correspond to both Skamnellian and Vlasian Stage glaciations.

Moraines at the heads of valleys on Chelmos are Late Pleistocene in age. The ${ }^{36} \mathrm{Cl}$ exposure ages from moraines at Kato Kambos (40-30 ka) suggest that the Late Pleistocene glacier maximum predates the global LGM. In other valleys the maximum Late Pleistocene moraines (associated with Unit 2 in Fig. 2) are undated. Nevertheless, whilst the succession of lower moraines ascribed to Unit 2 in the Neraidhovrisi valley (at c. $1600 \mathrm{~m}$ a.s.1.) are undated higher more proximal moraines ( $>2200 \mathrm{~m}$ a.s.1.) are dated to 23-21 ka. Thus, it is likely that moraine units depicted in Fig. 2 are diachronous reflecting maximum extents and later retreat phases. 
The largest Late Pleistocene glacier emanated northeastwards from the Neraidhorachi area and reached a length of c. $2 \mathrm{~km}$. In this valley glacier retreat appears to have been rapid with two successive moraine ridges in the highest part of the valley yielding ${ }^{36} \mathrm{Cl}$ ages that are indistinguishable within error with the last glacier in this valley retreating at 23-21 ka, just after the global LGM which occurred between 27 and $23 \mathrm{ka}$ (Hughes and Gibbard 2015). Glacier retreat at 23-21 ka ( $\pm 1.6 \mathrm{ka})$ is consistent with the evidence from northern Greece of dry conditions around the time of the LGM (cf. Hughes et al. 2003). In other valleys, such as Kato Kambos, there is evidence of a later phase of glaciation. This last phase of glaciation was characterised in this valley and possibly three others (although only the moraine at Kato Kambos is dated) by small cirque glaciers. Exposure ages reveal that this most recent phases of moraine building occurred between. 13 and $10 \mathrm{ka}$ and probably correlate with the Younger Dryas (12.9-11.7 ka). This phase of glaciation was associated with the strongest cirque forms (the four cirque areas are occupied by unit 3 moraines in Fig. 2 and the Phase III glaciers in Fig. 10). In other high valley areas without clearly developed cirques, such as in the upper Neraidhorachi valley at Epano Kambos, where unit 3 moraines are absent (Fig. 2),

The ${ }^{36} \mathrm{Cl}$ ages are calculated using the excel spreadsheet of Schimmelpfennig et al. (2009) and the authors are aware of continual refinements to the understanding of ${ }^{36} \mathrm{Cl}$ systematics, especially with regard to production rates. Thus, these exposure ages may change in future. Further work is underway to tighten the geochronology by applying U-series techniques to date secondary carbonate cements that are present in the moraines and also to apply optically stimulated luminescence (OSL) dating to glaciofluvial sands. Nevertheless, this paper presents the best available synthesis of the current knowledge of glaciation of Mount Chelmos and as with all research the precise glacial sequence may change as further evidence becomes available. Despite some uncertainties with the stratigraphical succession in some valleys, there is no doubt that: 1) Chelmos was glaciated by an ice cap during the most extensive glaciation; 2) Chelmos was glaciated on multiple occasions, the last being a phase of cirque glaciation, and 3) the Late Pleistocene glaciers reached their maximum earlier than the global LGM which is consistent with many other parts of the Mediterranean mountains.

In northern Greece, the Late Pleistocene glacial sequence is undated. However, on Mount Tymphi fluvial sediments downstream of the glaciated headwaters of the Voidomatis catchment have been dated and provide some constraint on the upstream glacial chronology (Hughes and Woodward, 2008). In this catchment, units comprising glacio-fluvial gravels have been dated to c. 28,200 to 24,300 years on the basis of a thermoluminescence date, three electron spin resonance dates and two U-series dates (Lewin et al. 1991; Hamlin et al, 2000; Woodward et al., 2008). The sand and silt matrix of this unit is dominated by limestone-rich fines which are derived from glacial erosion in the catchment headwaters (Lewin et al., 1991; Woodward et al., 1992). This geochronology is also 
supported by findings from the Italian Apennines where the largest glaciers during the Würmian occurred between $31,500 \pm 630{ }^{14} \mathrm{C}$ years BP $(34,770 \pm 638$ cal. years BP $)$ and $22,680 \pm 630{ }^{14} \mathrm{C}$ years BP (26,239 \pm 789 cal. years BP) (Giraudi and Frezzotti, 1997). Hughes et al. (2006c, p. 95) argued that "a strong candidate for the last local glacier maximum in the Pindus Mountains is the interval between 30,000 and 25,000 cal. years BP'. This assertion was reiterated by Giraudi (2012). However, the exposure ages of 30-40 ka obtained from Mount Chelmos predate this interval and are consistent with geochronologies showing evidence of a local glacier maximum that predates $30 \mathrm{ka}$ from Iberia (Serrano et al., 2012), the Pyrenees (Delmas et al. 2011) and Morocco (Hughes et al. 2011b). In Turkey there is evidence of a glacier davnce pre-dating the global LGM, although glaciers were at their largest at the LGM (Sarıkaya et al., 2014). The same is apparent across the Turkish mountains (e.g. Akçar et al., 2016; Çiner et al., 2016; Sarıkaya et al. 2016) where the LGM advance in MIS 2 was the largest advance of the last glacial cycle. Further work is needed to clarify the exact timing of the local glacial maximum on Mount Chelmos and, as with most places listed above from the Mediterranean and, indeed elsewhere around the world (Hughes et al., 2013), the evidence of an early glacier maximum needs testing and refining further. Nevertheless, the ${ }^{36} \mathrm{Cl}$ exposure ages from Chelmos clearly indicate limited ice extent in MIS 2with a succession of moraines in the highest area of Chelmos yielding the same ages (overlapping within error) which suggests rapid retreat close to the global LGM.

The most extensive ice cap glaciation was characterised by a single contiguous ice mass that covered an area of nearly $10 \mathrm{~km}^{2}$ with outlet glaciers extending 1.5 to $3.5 \mathrm{~km}$. The ice mass that submerged the central plateau of Chelmos was constrained by topography and hemmed in the central plateau area by the highest peaks of the massif. This and the fact that ice covered areas of $<100 \mathrm{~km}^{2}$ means that the ice mass that covered Chelmos is best described as a plateau ice field (cf. Rea et al., 1999; McDougall 2001; Evans et al., 2002; Rea and Evans 2003; Vieira 2008). The plateau ice field central dome would have raised the elevation of Mount Chelmos to $>2400 \mathrm{~m}$ above modern sea level. It is likely that increased areas at high elevation caused by the ice cap surface would have enhanced orographic effects on precipitation. This positive feedback effect would have been important in enhancing glacier development during the most extensive glaciations.

The average ELA of the largest Middle Pleistocene ice cap and associated outlet glaciers was $1984 \mathrm{~m}$. Two later generations of Late Pleistocene cirque glaciers had average ELAs of 1986 (30-40 ka) and $2114 \mathrm{~m}$ (Younger Dryas). The largest standard deviations are associated with the Phase I ice cap glacier reconstructions (Table 5) and this reflects large variability in the glacier front altitudes. The smallest standard deviations were associated with the smallest and highest cirque glaciers (Phase III) and this reflects the similar altitudes of the cirque basins on Chelmos. The Phase II glaciers had a similar ELA to the Phase I glaciers when applying an AAR of 0.6. This apparent paradox is because 
the Phase I ice cap caused an increase in the height of Chelmos since it submerged the landscape. The later Phase II glaciers then occupied incised cirques and valleys inherited from the Phase I glaciation. This meant that even with lower ELAs these glaciers were unable to reach thicknesses sufficient to submerge the mountain centre as a plateau ice field. It is also possible that the ELAs of the plateau ice field and associated outlet glaciers of Phase I were associated with a different AAR to the cirque and valley glaciers of Phase II. For example, Leonard (1984, p. 68) noted that AARs for ice caps may be as high as 0.8 . If an AAR of 0.8 is applied to the Phase I plateau ice field, then this corresponds to an ELA of $1854 \mathrm{~m}$ a.s.1., more than $100 \mathrm{~m}$ lower than the ELA of the Phase II glaciers estimated using an AAR of 0.6. In fact, for Montenegro, an AAR of 0.8 was applied for ice caps on Orjen and Durmitor (Hughes et al. 2010; 2011a) on the basis that this AAR was associated with the AAR with lowest standard deviation of altitude. For Chelmos, this was not the case and knowing which AAR is most appropriate for the different glacier phases is problematic and thus, the ELAs associated with all AARs are shown in Table 5.

In northern Greece, On Mount Tymphi, the largest Middle Pleistocene glaciers had an average ELA of $1741 \mathrm{~m}$ during the Skamnellian Stage (MIS 12). The Late Pleistocene Tymphian glaciers in this massif had an average |ELA of $2174 \mathrm{~m}$ a.s.1. Younger Dryas glaciers on Smolikas in northern Greece (they were absent on Tymphi) had an average ELA of $2425 \mathrm{~m}$. The largest Middle Pleistocene glaciation was characterised by ELAs that were $243 \mathrm{~m}$ higher in the Peloponnesus than in northern Greece. Conversely, the Late Pleistocene glaciers appear to have been lower in the Peloponnesus than in northern Greece. The Middle Pleistocene comparison is consistent with a warmer climate in the Peloponnesus compared with northern Greece (separated by $>2^{\circ}$ of latitude), whereas the Late Pleistocene comparison is the reverse of what one would expect. If the Late Pleistocene comparison is valid, and that Peloponnesus glaciers had lower ELAs than glaciers in northern Greece, then this must be explained by wetter conditions in the former. This is plausible if Late Pleistocene cold stage depressions had a more southerly track than today. A wider comparison, with Montenegro, c. $5-6^{\circ}$ to the north of the Peloponnesus, illustrates that the Pleistocene glaciers of Greece were significantly higher in all glacier phases (Table 4). For the Late Pleistocene, the Chelmos glaciers were 200-800 m higher than in Montenegro a situation forced not only by lower temperatures in Montenegro, but also higher precipitation, especially on the coastal mountains. The fact that ELAs appear to have been higher in northern Greece than in both Montenegro to the north and the Peloponnesus to the south either has major significance for understanding precipitation sources during the last cold stage or is an artefact of tectonic distortion of glacial landform altitudes over the past 30,000 years. As noted earlier, comparisons of ELAs are potentially compromised by different uplift histories (Bathrellos et al. 2016; Giraudi and Giaccio, 2016). Nevertheless, the suggestion that conditions were wetter on Mount Chelmos compared with mountains further north in Greece is consistent with the absence of Late Pleistocene rock glaciers in this massif. Whilst moraines are often substantial in terms of debris 
content on Mount Chelmos, they do not resemble the rock glaciers of northern Greece, which are often very clear and abundant (Hughes et al., 2003; Palmentola and Stamatopoulos 2006). Rock glaciers form when debris supply exceeds snow accumulation and thus tend to form under drier conditions than true glaciers (Haeberli, 1985; Belloni et al., 1988).

Tectonic uplift is known to affect the altitudes of Pleistocene glacial landforms in Greece (Bathrellos et al., 2014; Bathrellos et al., 2016) and other Mediterranean mountain areas (Giraudi and Giaccio, 2016). However, whilst tectonics movements are very active in the Northern Peloponnesus area, these are unlikely to affect reconstructed ELAs for the Late Pleistocene. Armijo et al. (1992) and McNeill et al. (2004) argue that Pleistocene and Holocene uplift rates are of the order of $1.5 \mathrm{~mm} \mathrm{yr}^{-1}$. This would mean that since the global Last Glacial Maximum (c. $25 \mathrm{ka}$ ) Chelmos has been uplifted by less than $40 \mathrm{~m}$. Locally, tectonic uplift may be greater than this, especially around active faults. It is also known that uplift has been greater during the Holocene than during the Pleistocene (Pirazzoli, et al., 2004). The southern coast of the Gulf of Corinth is complicated by numerous local faults (e.g. McNeill and Collier, 2004; Pirazzoli, et al., 2004; Palyvos et al., 2008; Pacchiani \& Lyon-Caen, 2010; Ford et al., 2013; including, from North to South, the Pyrgaki-Mamousia, Doumena, Kerpini and the Chelmos Faults and also the East Eliki Fault (all the faults strike East-West). The East Eliki Fault is usually considered as active whilst the southern faults are considered inactive, although there is discussion on the possible activity of Pyrgaki - Mamousia Fault, as there was an earthquake activity in 2004 (Agios Ioannis earthquake of magnitude 4.3) which was correlated with another fault, the Kerinitis Fault (Pacchiani \& Lyon-Caen, 2010). The Kerinitis fault has $50^{\circ} \mathrm{N}$ strike and it is thought to be a fault that connects two segments of the Pyrgaki-Mamousia Fault (Ford et al. 2013). Even with uplift rates estimated from this very active area of $3 \mathrm{~mm} \mathrm{yr}^{-1}$ for the Holocene (Pirazzoli, et al., 2004) and $1.5 \mathrm{~mm}$ $\mathrm{yr}^{-1}$.for the Late Pleistocene this would suggest uplift of just $30 \mathrm{~m}$ (Holocene) plus $22.5 \mathrm{~m}$ for the Late Pleistocene, making a potential total uplift of $52.5 \mathrm{~m}$ since $25 \mathrm{ka}$. Thus, given the small scale of potential uplift relative to the timescales under consideration and the uncertainties associated with providing an accurate value, no correction is warranted to account for uplift for Late Pleistocene glaciers reconstructed ELAs. In fact, since eustatic sea levels were $120 \mathrm{~m}$ lower around Greece (Lambeck, 1995), then the reconstructed ELAs (presented as above modern sea level) may be lower than if presented as above palaeo sea level. This would mean that Mount Chelmos was in fact higher above sea level during the Late Pleistocene than is the case today. This phenomenon was also noted for Tymphi in the North Pindus, where Hughes (2004, p. 227) noted that at around the time of the LGM "reconstructed ELAs will underestimate the 'real' ELA by 104 - 112 m". This calculation was based on an uplift rate for the Epirus region of 0.4-0.8 $\mathrm{mm} \mathrm{yr}^{-1}$ (King and Bailey, 1985). Beyond 300,000 years, uplift outstrips a minimum sea level depression of $120 \mathrm{~m}$ and reconstructed ELAs for the Skamnellian Stage (MIS 12) are likely to be overestimated rather than underestimated. Even with the greater uplift rates suggested for the Peloponnesus $\left(1.5 \mathrm{~mm} \mathrm{yr}^{-1}\right)$, only beyond c. 80,000 years 
does uplift outstrip cold stage sea level depressions. Thus, for the oldest and biggest glaciations recorded in Greece, which occurred during the Middle Pleistocene, the altitudinal difference between mountain ranges and sea-level is likely to have been lower than today.

The implications of the uplift discussion are that glaciers do appear to have been lower than in northern Greece during the Late Pleistocene and that this is not simply an artefact of uplift variations across Greece. This is highly significant because it implies that conditions in the Peloponnesus were more conducive for glaciation than in the northern Pindus. This is unlikely to be explained by temperatures but instead suggests that conditions were wetter in the Peloponnesus than in northern Greece during the glacier advances associated with the Late Pleistocene glacier maximum and also the Younger Dryas. The fact that further north, in Montenegro, glacier ELAs are substantially lower than in both northern and southern Greece, suggests that here the conditions were not only colder but wetter too. This implies that moisture bearing atmospheric systems that delivered winter snow to west-central Balkans and southernmost Greece were not the same. Winter precipitation in the westcentral Balkans is likely to have been caused by cyclogenesis in the northern Adriatic (Hughes et al. 2010) whereas in the Peloponnesus moisture-bearing atmospheric systems must have had a western or southern source. Whilst this may seem counter-intuative with regard to air temperatures it is moisture which is most important; and in a Pleistocene cold stage winter even southerly air masses would be sufficiently cold to deliver snow. This is consistent with recent findings from the Alps that depressions had a southerly track across the southern Mediterranean basin which then veered northwards approaching the Alps from the south (Luetscher et al. 2015). The trajectory of the jet stream over southern Europe indicated by Luetscher et al. (2015, their Fig. 1) is consistent with both cyclogenesis in the western Mediterranean (caused by a southerly jet stream source in this area) and also cyclogenesis in the northern Adriatic in the lee-side of the eastern Alps (caused by a northerly jet stream source in this area). However, further work is needed to constrain the timings of glaciations in both northern Greece and the west-central Balkans since in these areas Late Pleistocene moraines are either not dated or not precisely dated since U-series techniques provide only minimum ages (Hughes et al. 2010; 2011a). The success of ${ }^{36} \mathrm{Cl}$ in dating late Pleistocene moraine surfaces in the Peloponnesus as demonstrated in this paper will hopefully provide the incentive to now date other moraines across Greece and the west-central Balkans where limestone terrains dominate.

There is evidence that glaciers were present on other Peloponnesus mountains during the Pleistocene. Mastronuzzi et al. (1994) reported moraines in the cirques and valleys of the Taygetos (2404 m a.s.1.). In a large north-facing cirque (Actoctonios) multiple moraines are present down to $1500 \mathrm{~m}$ a.s.l. In the eastern cirques moraine crests are higher, situated between 1840 and $1880 \mathrm{~m}$ a.s.l. However, glacial landforms are also present below these moraines with roche moutonées present at $1740 \mathrm{~m}$ a.s.1. and it is possible that moraines are present in forested areas below the treeline. Pope (2013) noted that these 
glaciated catchments feed extensive fan formations in the Sparta area. Luminescence dating suggests that proximal fan sediments were deposited between $250 \mathrm{ka}$ to $130 \mathrm{ka}$ (MIS 8 to 6) (Pope and Wilkinson, 2006). However, the moraine and proximal fan soils differ significantly in terms of magnetic and iron properties, which are proxies of weathering (Pope and Millington 2000), and this may reflect a large age difference. The relationship between the Taygetos glaciations and the Sparta fans is the subject of ongoing research by the authors. Elsewhere in the Peloponnesus, little is known about the glacial history of the mountains. It is likely that glaciers comparable with those on Chelmos and the Taygetos are also present on Erimanthos (2124 m a.s.1.) to the west and Kyllini (2374 m a.s.1.) to the east.

\section{Conclusions}

There are at least three glacial phases recorded in the glacial geomorphology of Mount Chelmos. The oldest and largest is undated and is correlated with the large Middle Pleistocene glaciations recorded elsewhere in Greece and the wider Balkans. The moraines in the highest cirques have been dated, using ${ }^{36} \mathrm{Cl}$ exposure dating, and provide importantconstraints on the timings of Late Pleistocene glacier advance and retreat in Greece. The largest glaciers of the Late Pleistocene formed before 30 ka with less extensive recessional moraines dating close to the global LGM. Glaciers were therefore likely to have been present for over $10 \mathrm{ka}$ from MIS 3 through to MIS 2. Cirque moraines post-date the earlier moraines and are present in all the cirques of Chelmos. The ${ }^{36} \mathrm{Cl}$ exposure ages of $12.6 \pm$ 0.9 and $10.2 \pm 0.7 \mathrm{ka}$ are consistent with a Younger Dryas age for the last glaciers of Mount Chelmos. The Late Pleistocene moraine chronology from Mount Chelmos provides preliminary insight into glacier history of Greece during the last cold stage. The new ${ }^{36} \mathrm{Cl}$ exposure ages not only confirm earlier suggestions of an early glacier maximum, but also indicate the presence of glaciers in this area through the global LGM and also during the Younger Dryas. The absence of Late Pleistocene rock glaciers on Mount Chelmos may indicate wetter conditions in this area compared with further north in Greece, where rock glaciers are abundant.

\section{Acknowledgements}

We would like to thank the two reviewers for their very useful and detailed reviews which have helped improve this paper. We would like to thank Jon Yarwood (University of Manchester Geography Laboratories) for preparing rock samples for XRF and ICP-MS analysis. We would also like to thanks Paul Lythgoe (University of Manchester Earth Sciences Laboratories) for undertaking the XRF and ICP-MS measurements. The ${ }^{36} \mathrm{Cl}$ samples were processed and measured at PrimeLab, Purdue University. We would like to thank Irene Schimmelpfennig for advice on the use of the ${ }^{36} \mathrm{Cl}$ exposure age calculator. Funding for this project was provided by the University of Derby, the British Society for Geomorphology, and the Quaternary Research Association. 


\section{References}

Akçar, N., Yavuz, V., Yeşilyurt, S., Ivy-Ochs, S., Reber, R., Bayrakdar, C., Kubik, P.W., Zahno, C., Schlunegger, F., Schlüchter, C., 2016. A synchronous Last Glacial Maximum across the Anatolian peninsula. Geological Society, London, Special Publications, vol. 433.

Anavasi, 2008. Chelmos - Vouraikos [8.2]. Topo50. Peloponnesus. 1:50,000.

Armijo, R., Meyer, B., King, G.C.P., Rigo, A., Papanastassiou, D., 1996. Quaternary evolution of the Corinth Rift and its implications for the ate Cenozoic evolution of the Aegean. Geophysical Journal International 126, 11-53.

Bathrellos, G.D., Skilomidou, H.D., Maroukian, H., 2014. The spatial distribution of Middle and Late Pleistocene cirques in Greece. Geografiska Annaler, Series A, 96, 323-338.

Bathrellos, G.D., Skilodimou, H.D., Maroukian, H., 2016. The significance of tectonism in the glaciations of Greece. Geological Society, London, Special Publications, vol. 433.

Belloni, S, Pelfini, M., Smiraglia, C., 1988. Morphological features of the active rock glaciers in the Italian Alps and climatic correlations. Permafrost, Fifth International Conference (Trondheim), Proceedings 1, 678-682.

Benn, D.I., Hulton, N.R.J., 2010. An Excel $^{\mathrm{TM}}$ spreadsheet program for reconstructing the surface profile of former mountain glaciers and ice caps. Computers and Geosciences 36, 605-610.

Boenzi, F. and Palmentola, G. (1997) Glacial features and snow-line trend during the last glacial age in the southern Apennines (Italy) and on Albanian and Greek mountains. Zeitschrift für Geomorphologie 41, 21-29. 
Bottema, S., 1995. The Younger Dryas in the eastern Mediterranean. Quaternary Science Reviews 14, 883-891.

Çiner, A., Sarıkaya, M.A., Yıldırım, C., 2015. Late Pleistocene piedmont glaciations in the Eastern Mediterranean; insights from cosmogenic ${ }^{36} \mathrm{Cl}$ dating of hummocky moraines in southern Turkey. Quaternary Science Reviews 116, 44-56.

Çiner, A., Sarıkaya, M.A., 2016. Cosmogenic 36Cl gechronology of Quaternary glaciers on the Bolkar Mountains, south central Turkey. Geological Society, London, Special Publications, vol. 433.

Clark, D.H., Clark, M.M., Gillespie, A.R. 1994. Debris-covered glaciers in the Sierra Nevada, California, and their implications for snowline reconstructions. Quaternary Research 41, 139-153.

Collier, R.E.L., Leeder, M.R., Rowe, P.J., Atkinson, T.C., 1992. Rates of tectonic uplift in the Corinth and Megara Basins, central Greece. Tectonics 11, 1159-1167.

Delmas, M., Calvet, M., Gunnell, M., Braucher, R. and Bourlès, D. (2011) Palaeogeography and ${ }^{10} \mathrm{Be}$ exposure-age chronology of Middle and Late Pleistocene glacier systems in the northern Pyrenees: implications for reconstructing regional palaeoclimates. Palaeogeography, Palaeoclimatology, Palaeoecology 305:109-122.

Evans, D.J.A., Rea, B.R., Hansom, J.D., Whalley, W.B., 2002. Geomorphology and style of plateau icefield deglaciation in fjord terrains: the example of troms-Finnmark, north Norway. Jourbnal of Quaternary Science 17, 221-239.

Fabre, G. and Maire, R. (1983) Néotectonique et morphologénèse insulaire en Grèce: le massif du Mont Ida (Crète). Méditerranée 2, 39-40.

Federici, P.R., Granger, D.E., Pappalardo, M., Risolini, A., Spagnolo, M. and Cyr, A.J. (2008) Exposure age dating and Equilibrium Line Altitude reconstruction of an Egesen moraine in the Maritime Alps, Italy. Boreas 37:245-253. 
970

971

972

973

974

975

Federici, P. R., Granger, D. E., Ribolini, A., Spagnolo, M., Pappalardo, M., Cyr, A. J. 2012: Last Glacial Maximum and the Gschnitz stadial in the Maritime Alps according to ${ }^{10} \mathrm{Be}$ cosmogenic dating. Boreas 41, 277-291.

Ford, M., Rohais, S., Williams, E.A., Bourlange, S., Jousselin, D., Backert, N., Malartre, F. (2013) Tectono-sedimentary evolution of the western Corinth rift (Central Greece). Basin Research 25, 3-2

Giraudi, C. 2012. The Campo Felice Late Pleistocene Glaciation (Apennines, Central Italy). Journal of Quaternary Science 27, 432-440.

Giraudi, C., Frezzotti, M., 1997. Late Pleistocene glacial events in the Central Apennines, Italy. Quaternary Research 48, 280-290.

Giraudi, C., Giaccio, B., 2016. The Middle Pleistocene glaciations on the Apennines (Italy): new chronological data and considerations about the preservation of the glacial deposits. Geological Society, London, Special Publications, vol. 433.2016

Gosse, J.C. \& Phillips, F.M. (2001) Terrestrial in situ cosmogenic nuclides: theory and application. Quaternary Science Reviews 20, 1475-560.

Haeberli, W. (1985) Creep of mountain permafrost: internal structure and flow of alpine rock glaciers. Mitteilungen der Versuchsanstalt für Wasserbau, Hydrologie und Glaziologie 77, Zürich.

Hagedorn J. 1969. Beiträge zur Quartärmorphologie griechischer Hochgebirge. Göttinger Geographische Abhandlungen $50.135 \mathrm{pp}$.

Hamlin, R.H.B., Woodward, J.C., Black, S. and Macklin, M.G. (2000) Sediment fingerprinting as a tool for interpreting long-term river activity: the Voidomatis basin, Northwest Greece. In Foster, I.D.L. (ed) Tracers in Geomorphology. Wiley: Chichester. p. 473-501. 
994

Hughes, P.D. (2004) Quaternary glaciation in the Pindus Mountains, Northwest Greece. PhD thesis. University of Cambridge. $341 \mathrm{pp}$.

Hughes, P.D. (2010) The role of geomorphology in Quaternary stratigraphy:

morphostratigraphy, lithostratigraphy and allostratigraphy. Geomorphology 123, 189-199.

Hughes, P.D., Braithwaite, R.J. (2008) Application of a degree-day model to reconstruct Pleistocene glacial climates. Quaternary Research 69, 110-116.

Hughes, P.D and Woodward, J.C. (2008) Timing of glaciation in the Mediterranean mountains during the last cold stage. Journal of Quaternary Science 23:575-588.

Hughes, P.D., Gibbard, P.L. 2015. A stratigraphical basis for the Last Glacial Maximum (LGM). Quaternary International. DOI: 10.1016/j.quaint.2014.06.006

Hughes, P.D., Gibbard, P.L. and Woodward, J.C. (2003) Relict rock glaciers as indicators of Mediterranean palaeoclimate during the Last Glacial Maximum (Late Würmian) of northwest Greece. Journal of Quaternary Science 18, 431-440.

Hughes, P.D., Woodward, J.C., Gibbard, P.L., Macklin, M.G., Gilmour, M.A. and Smith, G.R. (2006a) The glacial history of the Pindus Mountains, Greece. Journal of Geology 114:413-434.

Hughes, P.D., Woodward, J.C. and Gibbard, P.L. (2006b) Glacial history of the Mediterranean mountains. Progress in Physical Geography 30:334-364.

Hughes, P.D., Woodward, J.C. and Gibbard, P.L. (2006c) Late Pleistocene glaciers and climate in the Mediterranean region. Global and Planetary Change 46:83-98.

Hughes, P.D., Woodward J.C. and Gibbard, P.L. (2006d) The last glaciers of Greece. Zeitschrift für Geomorphologie 50:37-61. 
Hughes, P.D., Gibbard, P.L. and Woodward, J.C. (2007a) Geological controls on Pleistocene glaciation and cirque form in Greece. Geomorphology 88:242-253.

Hughes, P.D., Woodward, J.C. and Gibbard, P.L. (2007b) Middle Pleistocene cold stage climates in the Mediterranean: new evidence from the glacial record. Earth and Planetary Science Letters 253:50-56.

Hughes, P.D., Woodward, J.C., van Calsteren, P.C., Thomas, L.E. and Adamson, K. (2010) Pleistocene ice caps on the coastal mountains of the Adriatic Sea: palaeoclimatic and wider palaeoenvironmental implications. Quaternary Science Reviews 29:3690-3708.

Hughes, P.D., Woodward, J.C., van Calsteren, P.C. and Thomas, L.E. (2011a) The glacial history of the Dinaric Alps, Montenegro. Quaternary Science Reviews 30:3393-3412.

Hughes, P.D., Fenton, C.R. and Gibbard, P.L. (2011b) Quaternary glaciations of the Atlas Mountains, North Africa. In: Ehlers, J., Gibbard, P.L. and Hughes, P.D. (eds), Quaternary Glaciations - Extent and Chronology, Part IV - A Closer Look. Amsterdam: Elsevier, pp. 1071-1080.

Hughes, P.D., Gibbard, P.L., Ehlers, J. 2013. Timing of glaciation during the last glacial cycle: evaluating the meaning and significance of the 'Last Glacial Maximum' (LGM). Earth Science Reviews 125, 171-198.

Ivy-Ochs, S., Poschinger, A. v., Synal, H.-A., Maisch, M., (2009) Surface exposure dating of the Flims landslide, Graubünden, Switzerland. Geomorphology 103, 104-112.

Jiménez Sanchez, M.,Farias Arquer, P. (2002) New radiometric and geomorphic evidences of a last glacial maximum older than $18 \mathrm{ka}$ in SW European mountains: the example of Redes Natural Park (Cantabrian Mountains, NW Spain). Geodinamica Acta 15:93-101.

Karkanas, P., 2001. Site formation processes in Theopetra cave: a record of climatic change during the Late Pleistocene and early Holocene in Thessaly, Greece. Geoarchaeology: An International Journal 16, 373-399. 
1069

1070

1071

1072

1073

1074

1075
King, G. and Bailey, G. (1985) The palaeoenvironment of Some Archaeological Sites in Greece: The influence of Accumulated Uplift in a Seismically Active Region. Proceedings of the Prehistoric Society 51, 273-282.

Koutsopoulos K, Sarlis G. (2003) Contribution to the study of the flora of Vouraikos gorge (Peloponnesos, Greece). Flora Mediterranea 12, 299-314.

Kuhlemann, J. Rohling, E.J., Krumrei, I., Kubik, P., Ivy-Ochs, S. and Kucera, M. (2008) Regional synthesis of Mediterranean atmospheric circulation during the last glacial maximum. Science 321:1338-1340.

Kuhlemann, J., Milivojević, M., Krumrei, I., Kubik, P.W., 2009. Last glaciation of the Sara range (Balkan peninsula): Increasing dryness from the LGM to the Holocene. Austrian Journal of Earth Sciences 102, 146-158.

Lambeck, K. (1995) Late Pleistocene and Holocene sea-level change in Greece and southwestern Turkey: a separation of eustatic, isostatic and tectonic contributions. Geophysical Journal International 122, 1022-1044.

Lawson, I.T., Frogley, M., Bryant, C., Preece, R., Tzedakis, P.C., 2004. The Lateglacial and Holocene environmental history of the Ioannina basin, north-west Greece. Quaternary Science Reviews 23, 1599-1625.

Le Dortz, K., Meyer, B., Sébrier, M., Braucher, R., Nazari, H., Benedetti, L., Fattahi, M., Bourlès, D., foroutan, M., Siame, L., Rashidi, A., Bateman, M.D., (2011) Dating inset terraces and offset fans along the Dehshir Fault (iran) combining cosmogenic and OSL methods. Geophysical Journal International 185, 1147-1174.

Leonard, E.M., 1984. Late Pleistocene equilibrium-line altitudes and modern snow accumulation patterns, San Juan Mountains, Colorado, U.S.A. Arctic and Alpine Research $16,65-76$.

Lewin, J., Macklin, M.G. and Woodward, J.C. (1991) Late Quaternary fluvial sedimentation in the Voidomatis Basin, Epirus, northwest Greece. Quaternary Research 35, 103-115. 
Licciardi J., Denoncourt C., Finkel R., 2008. Cosmogenic ${ }^{36} \mathrm{Cl}$ production rates from $\mathrm{Ca}$ spallation in Iceland. Earth Planetary Science Letters 267, 365-377. Luetscher, M., Boch, R., Sodemann, H., Spötl, C., Cheng, H., Edwards, R.L., Friscia, S., Hof, F., Müller, W., 2015. North Atlantic storm track changes during the Last Glacial maximum recorded by Alpine speleothems. Nature Communications DOI: 10.1038/ncomms7344

Manz, L.A. 1998. Cosmogenic ${ }^{36} \mathrm{Cl}$ chronology for deposits of presumed Pleistocene age on the Eastern Piedmont of Mount Olympus, Pieria, Greece. Unpublished MSc thesis, Ohio University, USA.

Mariolakos, I., Fountoulis, I., Marcopoulou-Diacantoni, A. \& Mirkou, M.R. 1994. Some remarks on the kinematic evolution of Messinia Province (SW Peloponnesus, Greece) during the Pleistocene based on neotectonic stratigraphic and paleoecological observations. Munstersche Forschungen zur Geologie und Palaontologie, 76, 371-380.

McNeill, L.C., Collier, R.E.L.I., (2004). Uplift and slip rates of the eastern Eliki fault segment, Gulf of Corinth, Greece, inferred from Holocene and Pleistocene terraces. Journal of the Geological Society of London, 161, 81-92.

Marrero, S., (2012). Calibration of Cosmogenic Chlorine-36, Earth \& Environmental Science. New Mexico Institute of Mining and Technology, Socorro, New Mexico, 365 pp.

Mastronuzzi, G., Sanso, P. and Stamatopoloulos, L. (1994) Glacial landforms of the Peloponnisos (Greece). Rivista Geografica Italiana 101, 77-86.

Mayor, A., Hayes, A., 2011. The Deadly Styx and the Death of Alexander.

Princeton/Stanford Working Papers in Classics. Version 1.3. May 2011. 30 pp.

McDougall, D.A., 2001. The geomorphological impact of Loch Lomond (Younger Dryas) Stadial plateau icefields in the central Lake District, northwest England. Journal of Quaternary Science 16, 531-543.

Messerli, B. (1967) Die eiszeitliche und die gegenwartige Vertgletscherung im Mittelemeeraum. Geographica Helvetica 22, 105-228. 
Mistardis, G. (1952) Recherches glaciologiques dans les parties supérieures des Monts Oeta et Oxya (Grèce Centrale). Zeitschrift für Gletscherkunde und Glazialgeologie 2, 72-79.

Moreno, A., Valero-Garcés, B.L., Jiménez-Sánchez, M. et al. (2010) The last deglaciation in the Picos de Europa National Park (Cantabrian Mountains, northern Spain). Journal of Quaternary Science 25:1076-1091.

Moretti, I., Sakellariou, D., Lykousis, V., Micarelli, L., 2003. The Gulf of Corinth: an active half graben? Journal of Geodynamics 36, 323-340.

Nieuwendam, A., Fernández, J.R., Oliva, M., Lopes, V., Cruces, A., Conceição, F., 2016. Postglacial landscape changes and cryogenic processes in in the Picos de Europa (northern Spain) reconstructed from geomorphological mapping and microstructures in quartz grains. Permafrost and Periglacial Processes. DOI: 10.1002/ppp.1853

Ohmura, A., Kasser, P. and Funk, M. (1992) Climate at the equilibrium line of glaciers. Journal of Glaciology 38, 397-411.

Osmaston, H. (2002) Chapter 9. The nature, extents and climates of former Quaternary tropical glaciers, with reference to the East African Mountains. In Kaser, G. and Osmaston, H. (eds) Tropical Glaciers. Cambridge University Press: Cambridge. p. 149-192.

Pacchiani, F., Lyon-Caen, H. (2010) Geometry and spatiotemporal evolution of the 2001 Agios Ioanis earthquake swarm (Corinth Rift, Greece). Geophysical Journal International, 180, 59-72.

Palacios, D., Marcos, J. de and Vázquez-Selem, L. (2011) Last Glacial Maximum and deglaciation of Sierra de Gredos, central Iberian Peninsula. Quaternary International 233:1626.

Palacios, D., Andrés, N. de, Marcos, J. de and Vázquez-Selem, L. (2012) Glacial landforms and their palaeoclimatic significance inj Sierra de Guadarrama, Central Iberian Peninsula. Geomorphology 139-140: 67-78. 
Pallàs, R., Rodés, Á., Braucher, R. et al. (2010) Small, isolated glacial catchments as priority targets for cosmogenic surface exposure dating of Pleistocene climate fluctuations, southeastern Pyrenees. Geology 38:891-894.

Palmentola, G., Stamatopoulos, L., 2006. Preliminary data about sporadic permafrost on Peristeri and Tzoumerka massifs (Pindos chain, Northwestern Greece). Revista de geomorphologie 8, 17-23.

Palmentola, G., Boenzi, F., Mastronuzzi, G., and Tromba, F. (1990a) Osservazioni sulle tracce glaciali del M. Timfi, catena del Pindo (Grecia). Geografia Fisica e Dinamica Quaternaria 13, 165-170.

Palyvos, N., Lemeille, F., Sorel, D., Pantosti, D. and Pavlopoulos, K. (2008). Geomorphic and biological indicators of paleoseismicity and Holocene uplift rate at a coastal normal fault footwall (western Corinth Gulf, Greece). Geomorphology, 96(1-2), 16-38.

Pechoux, P.Y. (1970) Traces of glacial action in the Mountains of Central Greece. Revue de Géographie Alpine 58, 211-224.

Pirazzoli, P.A., stiros, S.C., Fontugne, M., Arnold, M., (2004). Holocene and Quaternary uplift in the central part of the southern coast of the Corinth Gulf (Greece). Marine Geology, $212,35-44$.

Pope, R.J. (2013) Linking high altitude glacier melting to Late Quaternary sedimentation in environmentally sensitive range-front alluvial fans in the Sparta Basin, southern Greece. Geophemera 113, 13-18.

Pope, R.J.J., Millington, A.C., (2000). Unravelling the patterns of alluvial fan development using mineral magnetic analysis: Examples from the Sparta Basin, Lakonia, southern Greece. Earth Surface Processes and Landforms, 25, 601-615.

Pope, R., Wilkinson, K.N., (2006). Reconciling the roles of climate and tectonics in Late Quaternary fan development on the Spartan piedmont, Greece. Geological Society Special Publication 251, 133-152. 
Rea, B.R., Evans, D.J.A., 2003. Plateau icefield landsystems. In: Evans, D.J.A. (Ed.) Glacial Landsystems. Hodder Arnold, London. p. 407-431.

1181

Rea, B.R., Whalley, W.B., Dixon, T.S., Gordon, J.E., 1999. Plateau icefields as contributing area to valley glaciers and gthe potential impact on reconstructed ELAs: a case study from the Lyngen Alps, North Norway. Annals of Glaciology 28, 97-102.

1185

Sarıkaya, M.A., Çiner, A., 2016. The late Quaternary glaciations in the Eastern Mediterranean. Geological Society, London, Special Publications, vol. 433.

Rinterknecht, V., Matoshko, A., Gorokhovich, Y., Fabel, D., Xu, S., 2012. Expression of the Younger Dryas cold event in the Carpathian Mountains, Ukraine? Quaternary Science Reviews 39, 106-114.

Rodríguez-Rodríguez, L., Jiménez-Sánchez, M., Domínguez-Cuesta, M.J., Rinterknecht, V., Pallàs, R., Bourlès, D., Valero-Garcés, B., 2014. A multiple dating-method approach applied to Sabnabria Lake moraine complex (NW Iberian Peninsula, SW Europe). Quaternary Science Reviews 83, 1-10.

Ryb, U., Matmon, A., Erel, Y., Haviv, I., Katz, A., Starinsky, A., Angert, A., and ASTER Team (2014) Controls on denudation rates in tectonically stable Mediterranean carbonate terrain. Geological Society of America Bulletin 126, 553-568.

Sadier, B., Delannoy, J-J., Benedetti, L., Bourlès, D.L., Jaillet, S., Geneste, J-M., Lebatard, A-E., Arnold, M., (2012) Further constraints on the Chavet cave artwork elaboration.

Proceedings of the National Academy of Sciences 109, 21, 8002-8006.

Sarıkaya, M.A., 2014. Çiner, Haybat, H., Zreda, M., 2014. An early advance of glaciers on Mount Akdağ, SW Turkey, before the global Last Glacial maximum; insights from cosmogenic nulcides and glacier modelling. Quaternary Science Reviews 88, 96-109. 
Serrano, E., González-Trueba, J.J., Pellitero, R., González-García, M., Gómez-Lende, M., 2012. Quaternary glacial evolution in the Central Cantabrian Mountains (Northern Spain). Geomorphology 196, 65-82.

Serrano, E., González-Trueba, J.J., Pellitero, R., Gómez,-Lende, M., 2016. Quaternary glacial History of Cantabrian Mountain (Northern Spain): a new synthesis. Geological Society, London, Special Publications, vol. 433.

Sestini, A. (1933) Tracce glaciali sul Pindo epirota. Bollettino della Reale Società Geografica Italiano 10, 136-156.

Schimmelpfennig, I., Benedetti, L., Finkel, R., Pik, R., Blard, P.H., Bourles, D., Burnard, P., and Williams, A., 2009, Sources of in-situ Cl-36 in basaltic rocks. Implications for calibration of production rates: Quaternary Geochronology, v. 4, no. 6, p. 441-461.

Schimmelpfennig, I., Benedetti, L., Garret, V., Pik, R., Blard, P-H., Burnard, P., Bourlès, D., Finkel, R., Ammon, K., Dunai, T., 2011. Calibration of cosmogenic ${ }^{36} \mathrm{Cl}$ production rates from $\mathrm{Ca}$ and $\mathrm{Ka}$ spallation in lava flows from Etna $\left(38^{\circ} \mathrm{N}\right.$, Italy) and Payun Matru $\left(36^{\circ} \mathrm{S}, \mathrm{k}\right.$ Argentina). Geochimica et Cosmochimica Acta 75, 2611-2632.

Skourtsos, E. and Kranis, H. 2009. Structure and evolution of the western Corinth Rift, through new field data from the Northern Peloponnesus. In: U. Ring \& B. Wernicke (Eds.): Extending a Continent: Architecture, Rheology and Heat Budget. Geological Society, London, Special Publication, 321, p. 119-138, doi:10.1144/SP321.6.

Skourtsos, E., Lekkas, S. 2010. Extensional tectonics in Mt Parnon (Peloponnesus, Greece). International Journal of Earth Science (Geologische Rundschau), doi 10.1007/s00531-0100588-0.

Smith, G.W., Nance, R.D. and Genes, A.N. (1997) Quaternary glacial history of Mount Olympus. Geological Society of America Bulletin 109, 809-824. 
Stone, J., 2000, Air pressure and cosmogenic isotope production: Journal of Geophysical Research-Solid Earth, v. 105, no. B10, p. 23,753-23,759

Stone J. O., Allan G. L., Fifield L. K., Cresswell R. G., 1996. Cosmogenic 36Cl from calcium spallation. Geochimica Cosmochimica Acta 60, 679-692.

Van Husen, D., Ivy-Ochs, S., Alfimov, V., (2007) Mechanism and age of late glacial landslides in the Calcareous Alps; the Almtal, Upper Austria. Austrian Journal of Earth Sciences 100, 114-126.

Vieira, G.T. 2008. Combined numerical and geomorphological reconstruction of the Serra da estrela plateau icefield, Portugal. Geomorphology 97, 190-207.

Wilson, G.P., Reed, J.M., Lawson, I.T., Frogley, M.R., Preece, R.C., Tzedakis, P.C., 2008. Diatom response to the last Glacial-Interglacial transition in the Ioannina basin, northwest Greece: implications for Mediterranean palaeoclimate reconstruction. Quaternary Science Reviews 27, 428-440.

Woodward, J.C., Lewin, J., Macklin, M.G. 1992. Alluvial sediment sources in a glaciated catchment: the Voidomatis basin, northwest Greece. Earth Surface Processes and Landforms $16,205-216$.

Woodward, J.C., Lewin, J., Macklin, M.G., 1995. Glaciation, river behaviour and Palaeolithic settlement of upland northwest Greece. In: Lewin, J., Macklin, M.G., Woodward, J.C., (Eds) Mediterranean Quaternary River Environments. Balkema, Rotterdam. 115-129.

Woodward, J.C., Macklin, M.G. and Smith, G.R. (2004) Pleistocene Glaciation in the Mountains of Greece. In Ehlers, J. and Gibbard, P.L. (eds) Quaternary Glaciations - Extent and Chronology. Part I: Europe. Elsevier. p. 155-173.

Woodward, J.C., Hamlin, R.H.B., Macklin, M.G., Hughes, P.D. and Lewin, J. (2008) Glacial activity and catchment dynamics in northwest Greece: Long-term river behaviour and the slackwater sediment record for the last glacial to interglacial transition. Geomorphology 101:44-67. 
1275 Woodward, J.C. and Hughes, P.D. (2011) Glaciation in Greece: a new record of cold stage 1276 environments in the Mediterranean. In: Ehlers, J., Gibbard, P.L. and Hughes, P.D. (eds),

1277 Quaternary Glaciations - Extent and Chronology, Part IV - A Closer Look. Amsterdam:

1278 Elsevier: pp. 175-198.

1279

1280 World Meteorological Organisation, 1998. 1961-1990 global climate normals. Electronic

1281 resource. National Climatic Data Center, US: Asheville, NC. (CD-ROM).

1282

1283 
Figures

Figure 1. Location of Mount Chelmos in Greece showing the major tectonic features of the area.

Figure 2. Glacial geomorphological map of Mount Chelmos showing sample locations and exposure ages in red font.

Figure 3. Glacial boulders of Unit 1 in the Spanolakos valley. These represent the oldest glacial deposits in this valley. The boulders rest on cemented sands and gravels.

Figure 4. Clear arcuate end moraine in the Spanolakos valley (Unit 2).

Figure 5. Boulders sampled for ${ }^{36} \mathrm{Cl}$ exposure dating on a lateral moraine crest in the Kato Kambos valley. Foreground boulder is $\mathrm{CH} 8$ (with hammer) and the boulder near the person in the background is $\mathrm{CH} 7$. These boulders yielded exposure ages of $30.4 \pm 2.2 \mathrm{ka}$ and $39.6 \pm$ 3.0 , respectively.

Figure 6 . The cirque at Kato Kambos with bounding moraine ridge highlighted by sunlight (Unit 3).

Figure 7. Boulder sampled for exposure dating the Kato Kambos cirque (Unit 3).

Figure 8 . The lowest moraines in the Chaliki valley.

Figure 9. Cirque moraines southeast of spot height $2318 \mathrm{~m}$ (peak on the left side of photograph).

Figure 10. The three glacier phases on Mount Chelmos showing their relative sizes. 
1315

1316

1317

1318

\begin{tabular}{|c|c|c|c|c|c|c|c|c|}
\hline Sample & $\begin{array}{l}\text { Altitude } \\
\text { (m) }\end{array}$ & $\begin{array}{l}\text { Latitude } \\
\left({ }^{\circ} \mathrm{N}\right)\end{array}$ & $\begin{array}{l}\text { Longitude } \\
\left({ }^{\circ} \mathrm{E}\right)\end{array}$ & $\begin{array}{l}\text { scaling } \\
\text { factor for } \\
\text { nucleonic } \\
\text { production }^{1}\end{array}$ & $\begin{array}{l}\text { scaling } \\
\text { factor for } \\
\text { muonic } \\
\text { production }^{1}\end{array}$ & Thickness & Density $^{2}$ & Shielding $^{3}$ \\
\hline $\mathrm{CH} 2$ & 2250 & 37.9436 & 22.1969 & 5.1794 & 2.4875 & 1 & 2.5 & 0.995 \\
\hline $\mathrm{CH} 4$ & 2221 & 37.9757 & 22.1973 & 5.0839 & 2.4598 & 3 & 2.5 & 0.960 \\
\hline $\mathrm{CH} 5$ & 2209 & 37.9765 & 22.1973 & 5.0434 & 2.4481 & 2 & 2.5 & 0.960 \\
\hline $\mathrm{CH} 7$ & 2120 & 37.9674 & 22.1900 & 4.7493 & 2.3620 & 2 & 2.5 & 0.960 \\
\hline $\mathrm{CH} 8$ & 2121 & 37.9674 & 22.1903 & 4.7525 & 2.3629 & 5 & 2.5 & 0.950 \\
\hline $\mathrm{CH} 10$ & 2140 & 37.9655 & 22.1927 & 4.8137 & 2.3810 & 2 & 2.5 & 1.000 \\
\hline CH11 & 2139 & 37.9656 & 22.1927 & 4.8105 & 2.3801 & 5 & 2.7 & 0.980 \\
\hline
\end{tabular}

1319

1320

1321

1322

1323

1324

1325

\section{Tables}

Table 1. Sample details for ${ }^{36} \mathrm{Cl}$ analysis.

${ }^{1}$ Calculated following scaling factors and equations in Stone (2000).

${ }^{2}$ Measured using water displacement.

${ }^{3}$ Calculated using Cronus web calculator, available at

http://hess.ess.washington.edu/math/general/skyline input.php 


\begin{tabular}{|c|c|c|c|c|c|c|c|c|c|c|c|c|c|c|c|c|c|}
\hline Sample & \multicolumn{12}{|c|}{ Major elements } & \multicolumn{5}{|c|}{ Trace elements } \\
\hline $\mathrm{CH} 2$ & 47.870 & 0.488 & 0.137 & 1.042 & 8.805 & 0.112 & 0.728 & 2.601 & 0.068 & 0.108 & 37.900 & 0.173 & 35.916 & 0.687 & 0.953 & 1.142 & 2.427 \\
\hline CH5 & 47.048 & 0.499 & 0.160 & 1.090 & 9.401 & 0.107 & 0.079 & 2.824 & 0.059 & 0.070 & 37.900 & 0.099 & 74.670 & 1.445 & 1.579 & 2.573 & 5.085 \\
\hline CH7 & 49.662 & 0.423 & 0.130 & 1.058 & 7.560 & 0.117 & 0.907 & 2.293 & 0.067 & 0.083 & 37.600 & 0.111 & 35.621 & 0.771 & 0.981 & 1.562 & 6.158 \\
\hline CH8 & 52.708 & 0.255 & 0.080 & 0.603 & 4.308 & 0.086 & 0.668 & 1.486 & 0.046 & 0.058 & 39.600 & 0.069 & 83.543 & 1.500 & 1.744 & 2.028 & 4.463 \\
\hline CH10 & 54.174 & 0.165 & 0.062 & 0.440 & 5.831 & 0.076 & 0.540 & 1.090 & 0.077 & 0.059 & 37.400 & 0.064 & 83.734 & 1.403 & 1.887 & 1.919 & 2.972 \\
\hline
\end{tabular}

Formatted: Numbering: Continuous 


\begin{tabular}{|c|c|c|c|c|c|c|c|c|c|c|c|c|}
\hline $\begin{array}{c}\text { Sam } \\
\text { ple } \\
\text { nam } \\
\text { e }\end{array}$ & $\begin{array}{c}\text { Sam } \\
\text { ple } \\
\text { weig } \\
\text { ht } \\
\text { (g) }\end{array}$ & $\begin{array}{c}\text { Add } \\
\text { ed } \\
\text { spik } \\
\text { e } \\
(\mathrm{mg})\end{array}$ & $\begin{array}{l}{ }_{36} \mathrm{Cl} / \\
\mathrm{Cl} \\
(\mathrm{e}- \\
15)\end{array}$ & $\begin{array}{l}\text { Erro } \\
\text { r (e- } \\
15)\end{array}$ & $\begin{array}{c}{ }^{35} \mathrm{Cl} / \\
{ }^{37} \mathrm{Cl}\end{array}$ & $\begin{array}{c}\text { Erro } \\
\mathrm{r}\end{array}$ & $\begin{array}{l}\mathrm{Cl} \\
\text { (pp } \\
\mathrm{m})\end{array}$ & $\begin{array}{c}\text { Erro } \\
r \\
(\%)\end{array}$ & $\begin{array}{c}{ }^{36} \mathrm{Cl} \\
\text { atom } \\
/ \\
\text { sam } \\
\text { ple } \\
\text { (g) }\end{array}$ & $\begin{array}{c}\text { Erro } \\
\text { r \% }\end{array}$ & $\begin{array}{l}{ }^{36} \mathrm{Cl} \\
\text { expo } \\
\text { sure } \\
\text { age } \\
\text { (ka) }\end{array}$ & $\begin{array}{l}\text { Erro } \\
\mathrm{r} \\
\text { (ka) }\end{array}$ \\
\hline $\begin{array}{l}\mathrm{CH} 1 \\
1\end{array}$ & $\begin{array}{r}33.7 \\
353 \\
\end{array}$ & $\begin{array}{r}0.92 \\
75 \\
\end{array}$ & 863 & 20 & $\begin{array}{r}8.23 \\
9 \\
\end{array}$ & $\begin{array}{r}0.09 \\
3 \\
\end{array}$ & $\begin{array}{r}20.4 \\
00 \\
\end{array}$ & 2.1 & $\begin{array}{r}7135 \\
24 \\
\end{array}$ & 2.49 & $\begin{array}{r}10.1 \\
56 \\
\end{array}$ & $\begin{array}{r}0.72 \\
0 \\
\end{array}$ \\
\hline $\begin{array}{l}\text { CH1 } \\
0\end{array}$ & $\begin{array}{r}30.5 \\
065\end{array}$ & $\begin{array}{r}1.01 \\
08\end{array}$ & 1580 & 25 & $\begin{array}{r}13.7 \\
84\end{array}$ & $\begin{array}{r}0.00 \\
8\end{array}$ & $\begin{array}{r}11.3 \\
81\end{array}$ & 1.6 & $\begin{array}{r}1224 \\
632\end{array}$ & 1.61 & $\begin{array}{r}12.6 \\
13\end{array}$ & $\begin{array}{r}0.87 \\
3\end{array}$ \\
\hline $\mathrm{CH} 4$ & $\begin{array}{r}32.0 \\
071\end{array}$ & $\begin{array}{r}1.02 \\
10\end{array}$ & 2171 & 71 & $\begin{array}{r}8.62 \\
5\end{array}$ & $\begin{array}{r}0.01 \\
0\end{array}$ & $\begin{array}{r}22.5 \\
62\end{array}$ & 3.3 & $\begin{array}{r}2048 \\
733\end{array}$ & 3.28 & $\begin{array}{r}21.1 \\
52\end{array}$ & $\begin{array}{r}1.62 \\
8\end{array}$ \\
\hline CH5 & $\begin{array}{r}31.8 \\
594\end{array}$ & $\begin{array}{r}1.01 \\
97 \\
\end{array}$ & 2450 & 55 & $\begin{array}{r}16.1 \\
19 \\
\end{array}$ & $\begin{array}{r}0.02 \\
3 \\
\end{array}$ & $\begin{array}{r}8.77 \\
4 \\
\end{array}$ & 2.2 & $\begin{array}{r}1746 \\
687 \\
\end{array}$ & 2.24 & $\begin{array}{r}21.5 \\
86 \\
\end{array}$ & $\begin{array}{r}1.55 \\
3 \\
\end{array}$ \\
\hline $\mathrm{CH} 2$ & $\begin{array}{r}30.4 \\
977\end{array}$ & $\begin{array}{r}0.99 \\
38\end{array}$ & 2748 & 44 & $\begin{array}{r}12.8 \\
08\end{array}$ & $\begin{array}{r}0.11 \\
4\end{array}$ & $\begin{array}{r}11.8 \\
00\end{array}$ & 1.9 & $\begin{array}{r}2152 \\
481\end{array}$ & 1.65 & $\begin{array}{r}22.8 \\
50\end{array}$ & $\begin{array}{r}1.60 \\
6\end{array}$ \\
\hline CH7 & $\begin{array}{r}30.5 \\
769 \\
\end{array}$ & $\begin{array}{r}1.02 \\
34 \\
\end{array}$ & 4307 & 119 & $\begin{array}{r}14.2 \\
73 \\
\end{array}$ & $\begin{array}{r}0.05 \\
2 \\
\end{array}$ & $\begin{array}{r}11.7 \\
61\end{array}$ & 2.8 & $\begin{array}{r}3345 \\
379 \\
\end{array}$ & 2.76 & $\begin{array}{r}39.8 \\
50 \\
\end{array}$ & $\begin{array}{r}3.01 \\
3 \\
\end{array}$ \\
\hline CH8 & $\begin{array}{r}31.7 \\
567\end{array}$ & $\begin{array}{r}1.02 \\
50\end{array}$ & 3308 & 75 & $\begin{array}{r}12.3 \\
33\end{array}$ & $\begin{array}{r}0.03 \\
3\end{array}$ & $\begin{array}{r}13.0 \\
70\end{array}$ & 2.3 & $\begin{array}{r}2616 \\
728\end{array}$ & 2.28 & $\begin{array}{r}30.4 \\
17\end{array}$ & $\begin{array}{r}2.24 \\
7\end{array}$ \\
\hline
\end{tabular}

Formatted: Numbering: Continuous calculator of Schimmelpfennig et al. (2009). Order in descending order of calculated exposure age. 
1332 Table $4 .{ }^{36} \mathrm{Cl}$ exposure ages relative to the overall glacial stratigraphy and possible 1333 correlations with wider climatic events and stratigraphical units. No geochronology is 1334 available for the lowermost glacial deposits (Unit 1) and a Middle Plietsocene age is hypothesised based on correlations with dated moraines in northern Greece (Hughes et al.

1336 2006).

1337

\begin{tabular}{|l|l|l|l|}
\hline Stratigraphical Unit & ${ }^{36} \mathrm{Cl}$ Exposure Ages & & Correlations (tentative) \\
\hline 4 & $\begin{array}{l}12.6 \pm 0.9[\text { Kato Kambos] } \\
10.2 \pm 0.7[\text { Kato Kambos] }\end{array}$ & End moraine & $\begin{array}{l}\text { Younger Dryas } \\
\text { Glacier } \\
\text { stabilisation/advance }\end{array}$ \\
\hline 3 & $\begin{array}{l}21.2 \pm 1.6[\text { Epano Kambos] } \\
21.6 \pm 1.6[\text { Epano Kambos] } \\
22.9 \pm 1.6[\text { Epano Kambos] }\end{array}$ & $\begin{array}{l}\text { Recessional } \\
\text { moraines }\end{array}$ & $\begin{array}{l}\text { LGM } \\
\text { Glacier retreat }\end{array}$ \\
\hline 2 & $\begin{array}{l}39.9 \pm 3.0[\text { Kato Kambos] } \\
30.4 \pm 2.2[\text { Kato Kambos] }\end{array}$ & End moraine & $\begin{array}{l}\text { MIS 3 } \\
\text { Glacier } \\
\text { stabilisation/advance }\end{array}$ \\
\hline 1 & Undated & $\begin{array}{l}\text { Moraines and till } \\
\text { down-valley of unit } \\
2\end{array}$ & Middle Pleistocene \\
\hline
\end{tabular}




\begin{tabular}{|c|c|c|c|c|c|c|c|c|}
\hline PHASE I & Spanolakos & Strogilolaka & Kato Kambos & Chaliki & Neraidhorachi & Xerokambos & \multicolumn{2}{|c|}{ TOTAL AREA } \\
\hline Area $\left(\mathrm{km}^{2}\right)$ & 1.014 & 0.954 & 0.954 & 1.489 & 3.156 & 2.171 & \multicolumn{2}{|l|}{9.738} \\
\hline AAR & Altitudes (m) & & & & & & Mean & St Dev \\
\hline 0.4 & 2170 & 2240 & 2155 & 1900 & 2200 & 2120 & 2131 & 120.2 \\
\hline 0.5 & 2110 & 2195 & 2145 & 1840 & 1980 & 2065 & 2056 & 128.6 \\
\hline 0.6 & 2060 & 2160 & 2130 & 1765 & 1770 & 2020 & 1984 & 175.0 \\
\hline 0.7 & 2010 & 2130 & 2120 & 1700 & 1610 & 1960 & 1922 & 218.3 \\
\hline 0.8 & 1940 & 2090 & 2100 & 1625 & 1480 & 1890 & 1854 & 251.9 \\
\hline PHASE II & Spanolakos & & Kato Kambos & Chaliki & Neraidhorachi & Xerokambos & \multicolumn{2}{|c|}{ TOTAL AREA } \\
\hline Area $\left(\mathrm{km}^{2}\right)$ & 0.365 & & 0.676 & 0.802 & 1.623 & 0.979 & \multicolumn{2}{|c|}{4.445} \\
\hline AAR & Altitudes (m) & & & & & & Mean & St Dev \\
\hline 0.4 & 2060 & & 2200 & 2025 & 2025 & 2020 & 2066 & 76.6 \\
\hline 0.5 & 2050 & & 2175 & 1925 & 2000 & 1990 & 2028 & 93.4 \\
\hline 0.6 & 2040 & & 2160 & 1800 & 1970 & 1960 & 1986 & 131.1 \\
\hline 0.7 & 2030 & & 2150 & 1695 & 1925 & 1940 & 1948 & 167.4 \\
\hline 0.8 & 2015 & & 2140 & 1645 & 1900 & 1910 & 1922 & 182.7 \\
\hline PHASE III & Spanolakos & & Kato Kambos & Chaliki & & Xerokambos & \multicolumn{2}{|c|}{ TOTAL AREA } \\
\hline Area $\left(\mathrm{km}^{2}\right)$ & 0.134 & & 0.417 & 0.131 & & 0.050 & \multicolumn{2}{|r|}{0.866} \\
\hline AAR & Altitudes (m) & & & & & & Mean & St Dev \\
\hline 0.4 & 2070 & & 2186 & 2150 & & 2120 & 2135 & 50.3 \\
\hline 0.5 & 2060 & & 2178 & 2145 & & 2065 & 2125 & 53.3 \\
\hline 0.6 & 2045 & & 2172 & 2125 & & 2025 & 2114 & 55.3 \\
\hline 0.7 & 2035 & & 2164 & 2110 & & 1960 & 2101 & 59.4 \\
\hline 0.8 & 2020 & & 2155 & 2090 & & 1890 & 2085 & 62.0 \\
\hline
\end{tabular}

Table 5. Potential Equilibrium Line Altitudes (ELAs) associated with a range of Accumulation Area Ratios (AARs) for the three glaciers phases on Mount Chelmos. The most appropriate AAR may depend on the geometry and hypsometry of the former glaciers. For example, the ELAs of the ice cap and outlet glaciers associated with Phase I may not have been associated with the same AAR as the cirque and valley glaciers of Phases II and III. See main text for discussion. 


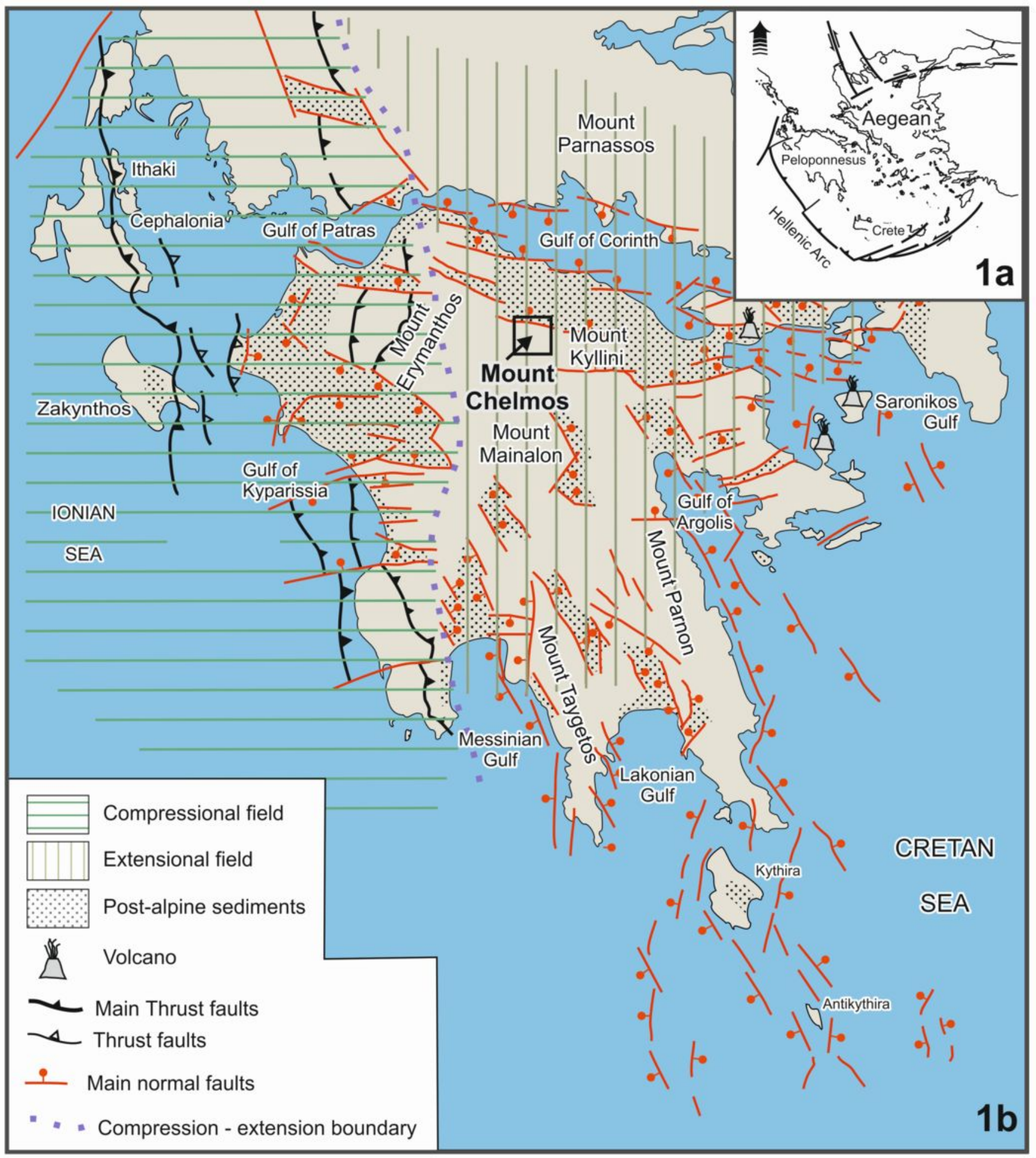




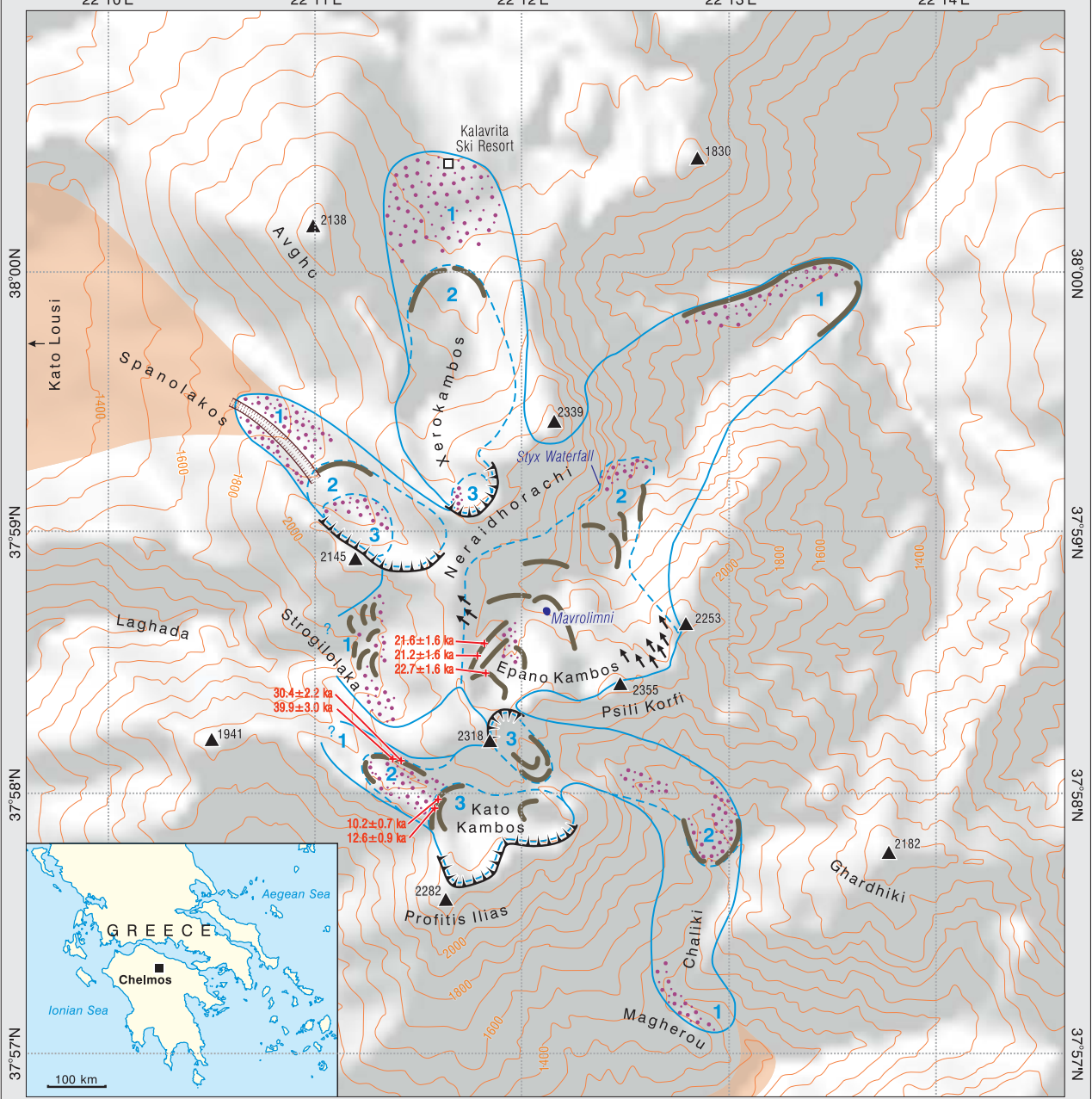

- Mountain summit (m a.s.l.)

․ Settlement

TT Cirque

Moraine ridge (clear morphology)

$\because \because$ Moraine/glacial boulders (indistinct)
Glaciofluvial deposits

tce moulded bedrock

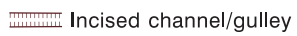

0 $2 \mathrm{~km}$
Maximum limit of glaciation

$-\frac{-}{2}-$ Stratigraphical unit 



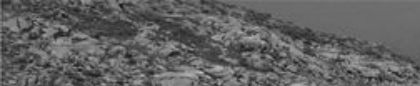

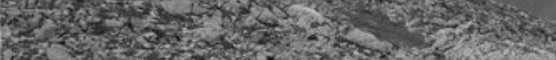

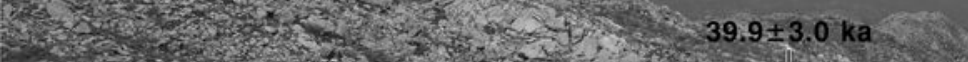

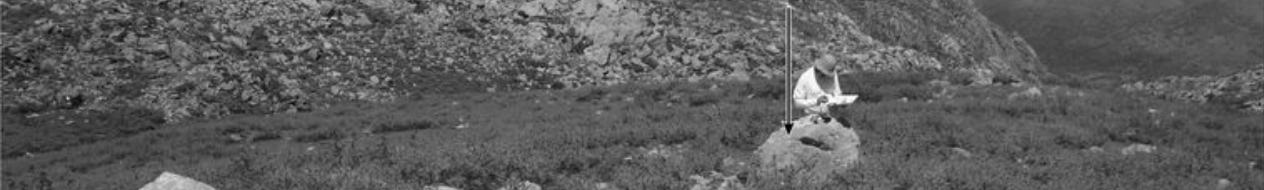

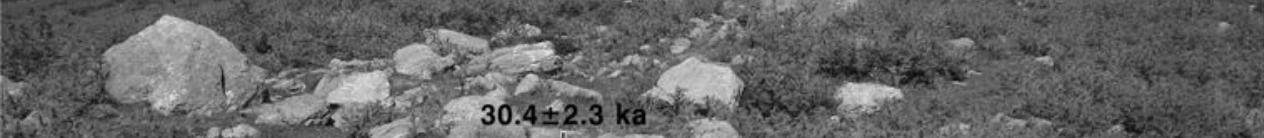

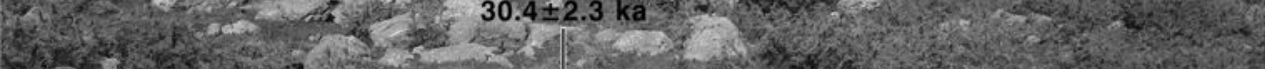

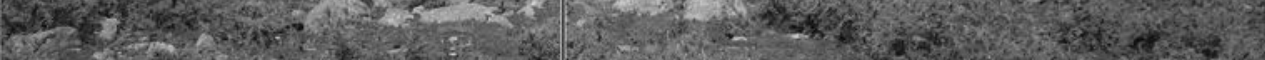

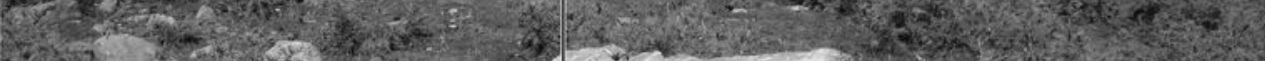

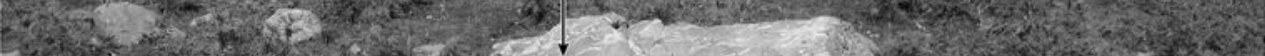

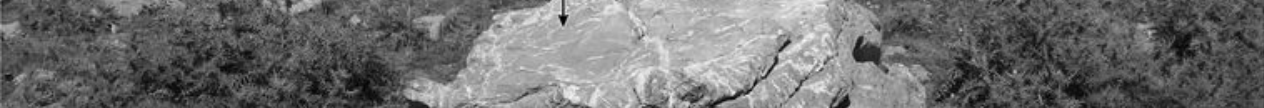

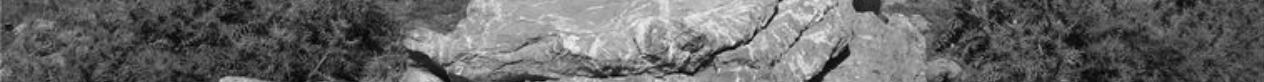

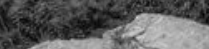

(1)

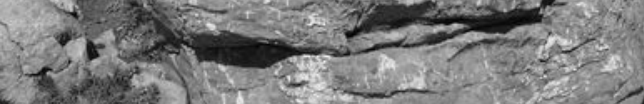

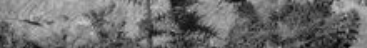

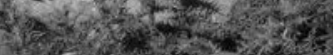

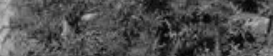

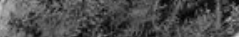
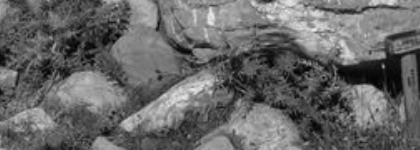
$12.6 \pm 0.9 \mathrm{ka}$

$10.2 \pm 0.7 \mathrm{ka}$ 

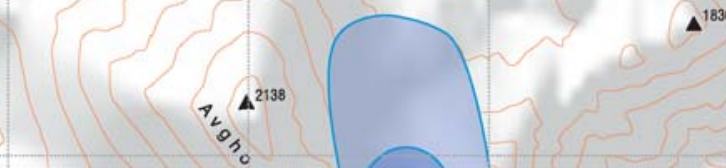

\section{Glacier reconstruction}

Phase III

Phase II 